IZA DP No. 9764

Competition and the Racial Wage Gap:

Testing Becker's Model of Employer Discrimination

Guilherme Hirata

Rodrigo R. Soares

February 2016 


\title{
Competition and the Racial Wage Gap: Testing Becker's Model of Employer Discrimination
}

\author{
Guilherme Hirata \\ IDados-Alfa e Beto Institute \\ Rodrigo R. Soares \\ Sao Paulo School of Economics-FGV \\ and IZA \\ Discussion Paper No. 9764 \\ February 2016 \\ IZA \\ P.O. Box 7240 \\ 53072 Bonn \\ Germany \\ Phone: +49-228-3894-0 \\ Fax: +49-228-3894-180 \\ E-mail: iza@iza.org
}

Any opinions expressed here are those of the author(s) and not those of IZA. Research published in this series may include views on policy, but the institute itself takes no institutional policy positions. The IZA research network is committed to the IZA Guiding Principles of Research Integrity.

The Institute for the Study of Labor (IZA) in Bonn is a local and virtual international research center and a place of communication between science, politics and business. IZA is an independent nonprofit organization supported by Deutsche Post Foundation. The center is associated with the University of Bonn and offers a stimulating research environment through its international network, workshops and conferences, data service, project support, research visits and doctoral program. IZA engages in (i) original and internationally competitive research in all fields of labor economics, (ii) development of policy concepts, and (iii) dissemination of research results and concepts to the interested public.

IZA Discussion Papers often represent preliminary work and are circulated to encourage discussion. Citation of such a paper should account for its provisional character. A revised version may be available directly from the author. 
IZA Discussion Paper No. 9764

February 2016

\title{
ABSTRACT \\ Competition and the Racial Wage Gap: Testing Becker's Model of Employer Discrimination*
}

\begin{abstract}
According to Becker's (1957) theory of taste-based employer discrimination, pure economic rents are necessary for discrimination to be observed in the labor market. Increased competition and reduced rents in the market for final goods should therefore lead to reduced labor market discrimination. We look at the natural experiment represented by the Brazilian trade liberalization from the early 1990s to study the effect of increased competition in the market for final goods on racial discrimination in the labor market. Changes in tariffs and initial employment structures are used to show that, in locations where there were relatively larger increases in exposure to foreign competition between 1990 and 1995, there were also relatively larger declines in the conditional racial wage gap between 1991 and 2000. As predicted by theory, the initial wage gap and its decline were more pronounced in regions with more employment in concentrated sectors. The effect of increased competition on the racial wage gap was not driven by changes in returns to productive attributes, in the structure of employment, or in other labor market outcomes. We find robust evidence of a negative effect of increased competition in the market for final goods on discrimination in the labor market.
\end{abstract}

JEL Classification: J31, J71, J78, F66

Keywords: discrimination, racial wage gap, competition, labor market, trade reform, Brazil

Corresponding author:

Rodrigo R. Soares

Sao Paulo School of Economics - FGV

Rua Itapeva 474, 120 Andar

01332-000 São Paulo, SP

Brazil

E-mail: rodrigo.reis.soares@fgv.br

\footnotetext{
* The authors wish to thank Gustavo Gonzaga, Naercio Menezes-Filho, and Cristina Terra for sharing their data. This paper benefited from comments from Claudio Ferraz, Gustavo Gonzaga, Brian Kovak, Naercio Menezes-Filho, David Neumark, Hugo Nopo, Vladimir Ponczek, Gabriel Ulyssea, and seminar participants at the $14^{\text {th }}$ IZA/SOLE Transatlantic Meeting of Labor Economists, the $10^{\text {th }}$ IZA/World Bank Conference on Employment and Development, the $3^{\text {rd }}$ LACEA Labor Network Meeting, the $1^{\text {st }}$ DATAZOOM Applied Micro Seminar, the $19^{\text {th }}$ LACEA Annual Meeting, EESP-FGV, Insper, IPEA-Rio, PUC-Rio, Tinbergen Institute, and USP-RP.
} 
IZA Discussion Paper No. 9764

February 2016

\section{NON-TECHNICAL SUMMARY}

We use the episode of trade liberalization in Brazil during the 1990s to test the effect of increased competition in the market for final goods on discrimination in the labor market. We show that local labor markets that experienced relatively higher exposure to international competition due to trade liberalization also observed relatively larger reductions in the conditional wage differential between white and black workers. As predicted by the theory of taste-based discrimination, the initial racial wage gap and the impact of increased competition were larger in local labor markets dominated by firms in more concentrated sectors.

Our results also incidentally imply that labor market discrimination due to racial prejudice is a prevalent phenomenon even in the case of Brazil, a highly mixed country often regarded as racially integrated. By exploring the issue of wage differentials across races, our paper also speaks to the broader literature on trade liberalization and inequality, and identifies a specific dimension over which increased openness contributed to reduce earnings inequality. Increased competition does appear as an important determinant of labor market discrimination, and policies that foster competition are therefore likely to be potentially important tools to fight racial discrimination in the marketplace. 


\section{Introduction}

Becker's (1957) theory of taste-based employer discrimination has a clear yet surprising implication: higher competition in the market for final goods should lead to lower discrimination against minorities in the labor market. This clear-cut conclusion comes from the fact that discrimination in the labor market requires the existence of pure economic rents. Only in the presence of rents can discriminating employers choose to pay certain workers below the value of their marginal productivities. This behavior creates opportunities for non-discriminating employers to enter the market and to hire more workers, paying higher wages and earning higher profits. Under perfect competition, when firms earn zero profit and pay each input the value of its marginal productivity, there is simply no scope for discrimination. Therefore some sort of market imperfection - such as the absence of free entry in the presence of decreasing returns to scale, or oligopolistic or monopolistic market structures - is required for labor market discrimination to be observed as an equilibrium outcome. In these contexts, increased competition in the market for final goods, by reducing pure economic rents, should lead to reduced discrimination in the labor market. Despite having been established almost 60 years ago, this implication of the theory of taste-based employer discrimination has been subject to surprisingly little convincing empirical scrutiny.

This paper uses the Brazilian trade liberalization episode from the early 1990s to test whether increased competition in the market for final goods is associated with reduced discrimination against blacks in the labor market. Brazil implemented a major unilateral reduction in import tariffs between 1990 and 1995. We analyze whether local labor markets that experienced relatively larger increases in exposure to international trade also experienced relatively larger reductions in the conditional wage gap between white and black workers. Local labor markets are defined as sets of geographically contiguous municipalities, representing roughly self-contained labor markets, classified as "micro-regions" by the Brazilian Census Bureau (Instituto Brasileiro de Geografia e Estatística, IBGE). We use changes in tariffs by sector and initial employment structures to calculate the relevant change in average tariffs from the perspective of each local labor market, following Kovak (2013). We concentrate on the reductions in tariffs that took place between 1990 and 1995, the period of effective trade liberalization in Brazil, and look mainly at data from the 1991 and 2000 censuses (though we also analyze data from 1980 and 2010 in some specifications).

Our empirical strategy is implemented in two stages. First, by running Mincer regressions, we estimate the conditional wage gap between white and black workers for each local labor market (micro-region) in 1991 and 2000. Following, in the second stage, we estimate the impact of 
increased openness on labor market discrimination by running, at the level of local labor markets, a regression of the estimated change in the conditional racial wage gap on the change in tariffs.

The results show that the conditional wage gap between whites and blacks fell more in regions associated with larger reductions in tariffs, or, in other words, in regions that experienced larger increases in exposure to international competition, as predicted by the theory of taste-based discrimination. According to our preferred specification, a reduction in tariffs equivalent to the average observed in the sample (9.7 percentage points) would lead to a reduction in the racial wage gap of $18 \%$. In fact, during the period of analysis, the conditional racial wage gap in Brazil remained roughly stable, so, abstracting from potential aggregate effects of the trade liberalization, the reduction in tariffs seems to have helped offset a trend towards increased racial inequality in the labor market. Our main result is robust to the composition of the sample and is not correlated with changes in returns to productive attributes, in the structure of employment, or in other observable labor market outcomes. In particular, the results are not associated with a Stolper-Samuelson effect, which might lead to relative gains for low skill workers and, possibly, to a reduction in the racial wage gap (if blacks are relatively less qualified in terms of unobserved skills). We also show that previous changes in the racial wage gap (between 1980 and 1991) were uncorrelated with future changes in tariffs (between 1991 and 2000), so that there is no evidence of differential pre-existing trends being correlated with the degree of increase in exposure to foreign competition. Finally, the results indicate that the effect of increased competition on the racial wage gap documented between 1991 and 2000 was permanent, remaining virtually unchanged up to 2010.

In order to provide additional supporting evidence to the mechanism highlighted in the theory of taste-based employer discrimination, we also analyze the heterogeneity of the estimated impact along certain margins. We show that the initial conditional racial wage gap and the impact of trade liberalization tended to be stronger in locations with more employment in concentrated sectors. According to theory, these are locations that should display initially higher levels of labor market discrimination and that should have responded more to increased competition.

There is a small but traditional literature on the effect of increased competition on discrimination against minorities, which focuses mostly on gender and not always tackles the identification challenges present in this type of analysis. Ashenfelter and Hannan (1986) look at the banking sector in the US and conclude that women have lower employment rates in more concentrated markets. Other papers use the deregulation of the banking and transportation sectors in the US as natural experiments on increased competition, finding results that support the theory 
(Black and Strahan, 2001, Peoples and Talley, 2001, and Levine et al., 2008). Zweimüller et al. (2008) analyze cross-country data and report a negative correlation between market friendly institutions such as openness to trade and protection of property rights - and the gender wage gap, meaning that higher economic freedom is associated with lower discrimination against women in the labor market. Kawaguchi (2007), using firm-level data for Japan, finds a positive correlation between proportion of women and profits. Hellerstein et al. (2002), using US data, estimate the same relationship for plants with high level of product market power. On the other hand, these two latter papers find no evidence that a low proportion of women leads to slower firm growth.

A recent literature, more closely related to this paper, explores the impact of international trade on wage inequality across genders. Black and Brainerd (2004) analyze the impact of increased competition from international trade on the gender wage gap in the US. They do not have a period of institutional change corresponding to a trade reform, so their empirical setting cannot be seen as a natural experiment, but they do find a negative correlation between exposure to international trade and the gender wage gap. Various other papers apply similar methodologies to analyze the response of the gender wage gap to trade reform in other countries - sometimes involving an explicit process of liberalization and others not -, including India, Mexico, South Korea, Taiwan, and groups of developed and developing countries (Artecona and Cunningham, 2002, Berik et al., 2004, Jacob, 2006, Oostendorp, 2009, Wolszczak-Derlacz, 2013). ${ }^{1}$ This body of research finds conflicting evidence on the impact of trade liberalization on the gender wage gap (see review in Anderson, 2005).

A limitation of these papers is the use of industry as the unit of analysis, which can be problematic given the relatively small number of observations and the fact that typically an industry cannot be considered a unified and independent labor market. In the presence of geographic labor market segmentation and spillovers across industries in the same area, this modelling choice is difficult to justify. This is a particularly serious concern in the case of developing countries, where migration, and therefore reallocation of labor across locations within the same industry, has been shown to be quite limited (see, for example, Topalova, 2010 for the case of India, Dix-Carneiro and Kovak, 2014 for Brazil, or Dix-Carneiro, 2012 for a review of the literature). In addition, the focus on gender discrimination presents considerable drawbacks. Women's labor supply decisions on the

\footnotetext{
${ }^{1}$ Jacob (2006) also analyzes the impact of trade on discrimination against lower castes, but finds no robust effect. Juhn et al. (2013) analyze the impact of NAFTA on the gender wage gap in Mexico, but highlight a mechanism that is different from discrimination. They show that the reduction in tariffs associated with NAFTA led industries to adopt new technologies that reduced the demand for physical labor, favoring women employed in blue collar occupations and reducing the gender inequality in the labor market. Though this mechanism is different from that discussed in the paper, it will be one of the alternative hypotheses considered when conducting our robustness exercises.
} 
extensive margin can be very important. This affects the predictions of Becker's (1957) theory in non-trivial ways, potentially weakening the link between competition in the market for final goods and labor market discrimination (as observed in wage differentials). In this case, the pattern and evolution of selection into the labor market, mostly ignored in this specific literature, become of first order relevance in determining the behavior of wage differentials and the impact of increased competition. These limitations associated with the use of industry as the unit of analysis and with the focus on gender discrimination can potentially explain the conflicting support to the theory of taste-based discrimination found in this literature.

We overcome these limitations by combining recent strategies that have not yet been applied to analyze the relationship between competition in the market for final goods and labor market discrimination. We use the Brazilian trade reform from the 1990s as a natural experiment generating an exogenous increase in competition in the market for final goods. As Topalova (2010) and Kovak (2013), we focus on local labor markets as the unit of analysis and use the initial structure of employment to calculate the relevant tariff reduction from the perspective of each local labor market. We then look at the impact of this exogenous change in exposure to foreign competition on the conditional racial wage gap, using an approach inspired by Charles and Guryan (2008). By looking at markets that are relatively self-contained and exploring an exogenous shock, we are able to arguably identify the change in equilibrium outcomes of specific labor markets, therefore improving upon the existing literature on trade liberalization and discrimination. In addition, differently from this literature, we concentrate on racial discrimination among prime aged men, rather than on gender discrimination, making participation decisions a second order issue and bringing the empirical exercise closer to the theory. Finally, differently from the previous papers, we are able to provide direct evidence in support of our key identifying assumption. We find robust evidence that increased competition in the market for final goods following the trade liberalization had a significant negative impact on labor market discrimination. Indirectly, our results point to the widespread prevalence of labor market discrimination due to racial prejudice even in the case of Brazil, a country with a highly mixed population and historically seen as racially integrated (see, for example, discussion in Theodoro, 2008).

This paper also speaks to a broader literature on the impacts of globalization on inequality in developing countries, based on the Heckscher-Ohlin model and the Stolper-Samuelson theorem. Goldberg and Pavnik (2007) review this literature and do not find robust evidence supporting the predictions of the theory. In fact, most of the literature documents increased inequality as a result of 
increased openness to international trade. In the case of Brazil, controversy still persists, with some studies finding a reduction in inequality due to the 1990s trade reform, and others pointing to null or even opposite effects (see, for example, Arbache and Menezes-Filho, 2000, Arbache and Corseuil, 2004, Gonzaga et al., 2006, Ferreira et al., 2010, Kovak, 2013, Dix-Carneiro and Kovak, 2015). We present evidence on one specific impact of the trade reforms that, in the case of Brazil, has unequivocally led to a reduction in labor market inequality.

The remainder of the paper is organized as follows. Section 2 sketches the simplest version of the model of taste-based employer discrimination proposed by Becker (1957) and discusses its empirical implications. Section 3 describes the process of trade reforms implemented in Brazil between 1988 and 1994. Section 4 discusses our identification strategy, explains the implementation of our empirical exercise, and presents the methodology for constructing tariffs at the level of local labor markets. Section 5 describes the data and the variables used, while Section 6 presents the results. Finally, Section 7 concludes the paper.

\section{The Model of Taste-based Employer Discrimination}

This model follows closely the original framework of Becker (1957). We outline the basics of the classic employer discrimination model to help guide our empirical discussion. Consider a population that is heterogeneous in terms of race, a non-productive attribute. There are individuals who belong to the racial minority - blacks $(b)$ - and individuals who belong to the racial majority whites $(w)-$, and both groups possess the same set of productive skills. In other words, blacks and whites are assumed to be perfect substitutes in production.

Employers potentially discriminate against members of the minority (blacks), in the sense that they attach a negative value to interacting with them or to having them as employees (assume, for example, that employers belong to the majority and that there is prejudice against the minority in this society). Following Becker (1957), we assume that this prejudice can be summarized by a coefficient of discrimination $\delta \geq 0$, which measures in relative monetary units the disutility that a given employer has when interacting with a member of the minority. In this setting, employers do not maximize profits, but instead a combination of profits and the disutility from interacting with members of the minority. Under these assumptions, the problem of an employer with coefficient of discrimination $\delta$ is

$\max _{\left\{L_{b}, L_{w}\right\}}\left\{F\left(L_{b}+L_{w}\right)-(1+\delta) \cdot W_{b} \cdot L_{b}-W_{w} \cdot L_{w}\right\}$ 
where the price of the final good is normalized to $1, F(\cdot)$ is the production function, $L_{i}$ indicates the number of workers of race $i$, and $W_{i}$ is the market wage for race $i$, with $i \in\{b, w\}$. $\delta$ can be interpreted as an additional subjective cost, above that represented by the wage, that the employer perceives when hiring someone from the minority group. The fact that $\delta$ represents tastes for discrimination as a proportion of the real wage is a simplifying assumption and has no consequence in terms of the qualitative implications of the model.

The problem of the employer is to choose $L_{b}$ and $L_{w}$ to maximize the function above. In a competitive labor market, where wages are taken as given, the first order conditions for this problem are

$F_{L_{w}^{*}} \leq W_{w}$, with equality if $L_{w}^{*}>0$, and

$F_{L_{b}^{*}} \leq(1+\delta) \cdot W_{b}$, with equality if $L_{b}^{*}>0$.

Since $L_{b}$ and $L_{w}$ are assumed to be perfect substitutes in production, $F_{L b}=F_{L w}$. This implies that, typically, an employer hires only black or white workers, but not both simultaneously. If the coefficient of discrimination is such that $W_{w}<W_{b \cdot}(1+\delta)$, the employer hires only white workers and, otherwise, he hires only black workers. In this setting, market forces induce employers who do not discriminate or who discriminate less to hire only black workers, and those with higher coefficients of discrimination to hire only white workers.

In order to discuss some features of the equilibrium characterizing this economy, assume that there is a continuum of measure $N_{e}$ of employers, over which $\delta$ is distributed according to some distribution function $H(\delta)$. Given the equilibrium wages $W_{b}$ and $W_{w}$, there must be some employer with $\delta=\delta_{m}$ for which the following condition holds

$W_{w}=W_{b}\left(1+\delta_{m}\right)$

We call this employer with $\delta=\delta_{m}$ the marginal employer. He is the employer who is indifferent between hiring workers from the minority or the majority. Alternatively, he is the employer with the highest coefficient of discrimination who is still willing to hire workers from the minority.

The coefficient of discrimination of the marginal employer, $\delta_{m}$, corresponds to the equilibrium wage gap between whites and blacks: $\left(1+\delta_{m}\right)=W_{w} / W_{b}$. If $\delta_{m}=0$, there is no racial wage gap in 
equilibrium, despite the fact that there may be some employers with $\delta>0$ in the population. So the determination of the equilibrium racial wage gap in this economy is equivalent to the determination of the identity of this marginal employer. A simple example helps clarify the relevant forces at work.

Following Becker (1957), consider a fixed supply $S_{b}$ of workers from the minority group and focus on a partial equilibrium analysis looking at the demand for minority workers as a function of the racial wage gap. For an employer who hires only minority workers, define the optimal demand for labor as a function of $\delta$ as $L_{b}{ }^{*}(\delta)$, determined implicitly from $F_{L}\left(L_{b}{ }^{*}\right)=(1+\delta)$. $W_{b}$. Employers hiring minority workers are those with $\delta \leq \delta_{m}=\left(W_{w} / W_{b}\right)-1$. So the demand for minority workers as a function of $W_{b} / W_{w}$ can be written as

$D_{b}\left(\frac{W_{b}}{W_{w}}\right)=N_{e} \int_{0}^{\left(W_{w} / W_{b}\right)-1} L_{b}^{*}(\delta) \cdot d H(\delta)$.

The equilibrium racial wage gap in this economy, as well as the identity of the marginal employer of minority workers, is determined from the equality between the supply and demand of minority workers: $D_{b}\left(W_{b} / W_{w}\right)=S_{b}$. This simple model highlights the forces intervening in the determination of $W_{b} / W_{w}$ and informs our empirical analysis.

First, there can only be labor market discrimination in equilibrium if the number of employers $N_{e}$ is given and if there are decreasing returns to scale. With free entry and a pool of potential employers with $\delta=0$, non-discriminating employers would enter the market until discrimination were eliminated. This would have to be the case, since $F_{L b}>W_{b}$ implies an allocative inefficiency that opens up opportunities for increased profits for non-discriminating firms. Similarly, without decreasing returns to scale, employers with $\delta=0$ would grow and eventually take over the market, also eliminating any observed wage gap between minority and majority. So taste-based discrimination in the labor market requires some degree of inefficiency and the existence of pure economic rents. Increased competition in the form of new entrants and reduced rents should reduce the equilibrium level of discrimination.

In addition, the model also reveals other characteristics of markets where we should expect to see higher levels of labor market discrimination. For a given supply of minority workers, the distribution of preferences for discrimination $(\delta)$ is the key determinant of the observed wage differential between races. Not surprisingly, a homogeneous rightward shift in the coefficient of discrimination should increase observed labor market discrimination. More surprising maybe is the fact that increases in the size of the minority, for a given distribution of $\delta$ and number of employers, 
should also increase labor market discrimination. This implication comes from the fact that an increase in the supply of minority workers, in equilibrium, would have to induce an increase in $\delta_{m}$ (the marginal employer of minority workers would have to be someone with a higher $\delta$ ), which could only happen through an increase in the racial wage gap.

Figure 1 illustrates these two points in a graph where the equilibrium demand for minority workers (in the horizontal axis) is plotted as a function of the racial wage gap (in the vertical axis). The relative demand curve $D_{b}^{2}$ represents a rightward shift in the discrimination coefficient in comparison to $D_{b}{ }^{1}$, while the supply curve $S_{b}^{2}$ represents an increased supply of minority workers in comparison to $S_{b}$. The movement from point I to point II summarizes the effect of an increase in prejudice among employers on observed labor market discrimination. The movement from point I to point III depicts the effect of a rightward shift in the supply of minority workers. As illustrated in the figure, both changes lead to an increase in the equilibrium racial wage gap.

We use the simplest version of the theory of taste-based employer discrimination to highlight some key theoretical implications that are relevant to analyzing the data. Recent treatments have extended this analysis to richer theoretical settings, in which the robustness of some of these implications can be tested. Ederignton and Sandford (2013), for example, look at a dynamic model of monopolistic competition with sunk costs and sequential entry. They show that firms that discriminate less are more likely to survive in the long-run, that increased competition reduces the equilibrium level of labor market discrimination, and that the effect of increased competition is particularly strong when firms operate in more concentrated markets for final goods.

Two implications of this model should be kept in mind for our later empirical discussion. First, increased competition should lead to reduced labor market discrimination. Second, one should expect to see higher levels of discrimination where production in the final goods market is more concentrated, where there is a higher level of prejudice among the overall population, and where there is a higher share of minority workers.

\section{The 1990s Trade Reform in Brazil}

From 1957 to 1988, there was little change in trade legislation in Brazil.2 During this period, there was widespread use of non-tariff barriers, including quotas and lists restricting the variety and quantity of goods that could be imported. The redundancy of tariffs and the existence of various

2 Our description of the trade reform is based to a great extent on Kume et al. (2003). For further details on the process of trade liberalization in Brazil, refer to these authors. 
additional taxes - such as, for example, the additional freight fee for renewal of the Merchant Navy -, besides 42 special regimes allowing for tariff exemptions or reductions, generated a heavily bureaucratic structure, distorting relative prices. As a result, Brazil had very little exposure to competition from foreign goods.

Planning of the trade reform started in 1987, during the Sarney government. But implementation was halted due to pressure from interests groups who wanted to maintain the trade barriers in certain sectors. Between 1988 and 1989, the government managed to eliminate only the redundant part of the tariff structure and reduce part of the non-tariff barriers. The process of liberalization was reinitiated under the Collor and Franco governments. Starting in 1990, non-tariff barriers and special regimes were eliminated and typically immediately replaced by equivalent import tariffs, in a process known as "tariffication." This left the actual protection structure unaltered, but effectively turned tariffs into the main instrument for trade policy. Additionally, a timeline for the gradual reduction of tariffs was approved and implemented. Initially planned to be executed until 1994, the timing was anticipated and by the end of 1993 the major part of tariff reductions had already taken place. In a further movement towards openness, the Cardoso government reduced some additional tariffs in 1994, as part of a broader effort focused on economic stabilization (Real Plan). Overall, one can see the tariffs in 1990 as accurately reflecting the historical levels of trade protection in Brazil, and the reductions in tariffs between 1990 and 1995 as capturing the main implications of the reform in terms of exposure of the domestic industry to foreign competition.

Figure 2 portrays the evolution of nominal tariffs in Brazil between 1987 and 1998 for the 10 sectors with the highest shares of employment (data from Kume et al., 2003). There is a clear pattern of generalized reduction and homogenization of tariffs up until 1994, when the minimum levels are attained in most sectors. During this period, the simple average of tariffs reductions across manufacturing sectors was 43 percentage points (75\%). As a result, the share of trade in the Brazilian GDP increased from around 15\% in the second half of the 1980s, to $22 \%$ in 2000 (data from the World Development Indicators).

We focus on nominal tariffs throughout the paper. At the level of industry aggregation we use, which is the one that makes the data from Kume et al. (2003) compatible with the census, nominal tariffs are almost perfectly correlated with effective tariffs, so this decision is of no consequence to the results. Dix-Carneiro et al. (2016) report that tariff changes at the level of local labor markets 
calculated using output tariffs and effective rates of protection display a coefficient of correlation of 0.99 .

It is worth pointing out that, as the figure makes clear, there was a very mild reversion in the trend towards increased openness after 1995. This was mostly a response of the Brazilian government to domestic pressures derived from the international financial crises of the late 1990s. In any case, this mild reversion pales in comparison to the magnitude of the reductions in tariffs from the first half of the 1990s. In effect, import tariffs remained virtually constant in Brazil after the reform at least until 2010, reflecting the levels attained in 1995.

Figure 3 presents the evolution of Brazilian imports by sector from 1985 to 1999. For each sector, the real value of imports (in 1999 Brazilian Reais) is normalized to 1 in 1985 (data from Gonzaga et al., 2006). Apart from apparel and textiles, imports are stable until 1991, without any clear trend. But, starting in the first half of the 1990s, there is a sharp change in trend towards increased imports in most sectors. Even for apparel and textiles, for which imports started increasing already before 1990, there is a strong acceleration in the growth rate after 1992. Increases in imports in the short period between the early 1990s and 2000 are way above $200 \%$ for the majority of sectors portrayed in the figure. The data show that the reductions in tariffs from Figure 2 had major effects for local producers, representing real increases in exposure to foreign competition and, most likely, reductions in market power and profits.

A large literature has analyzed various dimensions of labor market impacts of the 1990s trade reform in Brazil. Gonzaga et al. (2006), for example, look at the effect of the reform on earnings differentials across levels of schooling. More recently, papers within the local labor markets literature - such as Kovak (2013) and Dix-Carneiro and Kovak (2015a and 2015b) - have analyzed the medium- and long-run consequences of the reform in terms of wages, employment, informality, and skill-premium. The local labor markets literature assumes that, by increasing competition in the market for final goods, the trade liberalization reduced the demand for labor in regions that had a higher concentration of employment in sectors that suffered larger reductions in tariffs (when compared to other regions). Consistent with this view, this literature documents that the labor demand shocks induced by the liberalization had large effects on wages and employment in the medium run (2000), which were followed by a recovery - virtually complete in the case of employment, but only partial for wages - in the long run (2010).

Though there is no direct evidence available on procompetitive effects of the trade liberalization on firms' profit margins or mark ups for the case of Brazil, this type of evidence has 
been recently documented for various other trade reforms around the world (see, for example, Edmond et al., 2015, Lu and Yu, 2015, De Locker et al., 2016). The labor market responses to the trade reform in the case of Brazil are consistent with these procompetitive effects, and can be seen as driven by changes in labor demand from firms facing reduced profit margins and increased competition in the market for final goods.

Three characteristics of the trade reform in Brazil are particularly important for our empirical strategy. First, it was very sharp and concentrated in time: in a period of roughly 5 years, trade barriers were aggressively reduced and large increases in imports were observed. Second, liberalization was driven by a centralized decision at the federal level, unrelated to economic conditions in local labor markets. And third, sectors differed greatly both in terms of the distribution of employment across regions and of tariff cuts, generating large geographic heterogeneity in the impact of the reform. We come back to these points in our discussion of the empirical strategy in the next section.

\section{Methodology}

\subsection{Identification}

We use the episode of trade liberalization in Brazil as a natural experiment to assess the impact of increased competition in the market for final goods on discrimination in the labor market. We combine the reduction in tariffs triggered by the reform with the regional variation in the structure of employment to explore the geographically heterogeneous effects of the reform on exposure to foreign competition.

As mentioned in the previous section, the trade liberalization was concentrated in time almost in a discrete fashion. Though some tariffs were eliminated and others reduced between 1987 and 1990, these first changes represented mostly a rationalization of the tariff structure and had little impact on actual trade protection (Kume et al., 2003). It was really only in the 1990s that liberalization started taking place. Following Kovak (2013), our analysis focuses on the reductions in tariffs observed between 1990 and 1995, and uses data from the 1991 and 2000 censuses as representing, respectively, the starting point before the reform and the new equilibrium in the Brazilian labor market following liberalization.

A potential concern with this identification strategy is that reductions in tariffs might have been determined by the political influence of interest groups, which in turn might have been affected 
by labor market conditions. In this hypothetical setting, tariff reductions would be endogenous to labor market conditions and the identification strategy would be compromised. Figure 4 shows that this does not seem to be the case. The figure plots, by sector of activity, the 1990-1995 tariff reduction in the vertical axis (percentage points) against the initial tariff level in the horizontal axis. The pattern shows that the reform led to a homogenization of tariffs: sectors with initially higher tariffs experienced larger subsequent reductions in tariffs. The average tariff reduction of $60 \%$ during this period was accompanied by a reduction of $53 \%$ in the sectorial dispersion of tariffs (standard deviation).

The unit of analysis in our empirical exercise is a local labor market, defined as a microregion, not a sector of economic activity as in Figure 4. So Figure 5 reproduces the same diagram from Figure 4 but for average tariffs at the level of local labor markets. We discuss how these average tariffs are constructed at the end of this section, but mention the data before to inform our discussion on identification. The pattern is even more extreme than that observed in Figure 4: micro-regions with initially higher tariffs experienced larger subsequent reductions in tariffs. In Figure 5, this relationship is linear and close to deterministic. Again, average reductions in tariffs in micro-regions did not seem to be correlated with previous changes in labor market conditions. Notwithstanding the evidence from Figure 5, we also consider explicitly this possibility in the results section.

It is worth mentioning that the average tariff reduction by micro-regions is lower than that observed across sectors. This comes from the fact that employment shares are used to construct average tariffs by micro-region, and some sectors with large employment shares had very small reductions in tariffs after 1990 (this is the case, for example, for the agricultural sector, which accounted for half of the employment outside of the services sector; see Appendix Table A.1).

\subsection{Empirical Strategy}

We estimate the impact of the reduction in tariffs on the racial wage gap in two stages. First, we run individual level Mincer regressions to estimate the conditional wage gap between whites and blacks in each local labor market in 1991 and 2000. Following, the estimated conditional wage gaps are used to construct the dependent variable for the second stage: the change in the wage gap between 1991 and 2000. The change in the racial wage gap is then regressed on the change in tariffs between 1990 and 1995. In the second stage, the unit of analysis is a local labor market, which we define as a micro-region (as mentioned before, a set of contiguous municipalities with similar geographic and socioeconomic conditions, defined by the Brazilian Census Bureau, IBGE). We use a 
micro-region as a local labor market, instead of a municipality, following Kovak (2013) and DixCarneiro and Kovak (2015a and 2015b). Also, due to the reduced number of observations for smaller municipalities in the census long questionnaire, it is difficult to estimate the racial wage gap with precision at the municipality level.

\section{First Stage}

In the first stage, we estimate the conditional racial wage gap for 1991 and 2000, controlling for correlates of individual productivity. For each year $t$, we estimate individual level Mincer regressions by OLS. Our basic specification is the following:

$\ln$ wages $_{i j t}=\alpha_{t}+\sum_{j} \delta_{j t}$ white $_{i j t} \times$ micro_region $_{j t}+\gamma_{t}{ }^{\prime} \boldsymbol{X}_{i j t}+\varepsilon_{i j t}$,

where $i$ indicates individual, $j$ indicates micro-region, wages denote hourly earnings, white is a dummy for race (equal to 1 for whites and Asians, and 0 for blacks and mixed), micro_region is a dummy equal to 1 for region $j, \boldsymbol{X}$ is a vector of demographic controls, and $\varepsilon$ is a random term. In the benchmark specification, the vector $\boldsymbol{X}$ includes age, age squared, an entirely flexible function of years of schooling (one dummy for each completed year of schooling), a dummy indicating urban residence, and a dummy for each micro-region. This same specification is estimated separately for 1991 and 2000.

Our focus in the first stage is on the coefficient $\delta_{j t}$, which we call the conditional racial wage gap for local labor market $j$ in year $t$. Specifically, $\delta_{j t}$ indicates the wage advantage of a white worker in comparison to a black worker with similar observable characteristics. The fact that we estimate the equation separately for each year means that parameters can change from one year to the other, reflecting potential changes in returns to productive attributes due to labor market conditions. In some robustness exercises, we run equation 6 separately for each micro-region, allowing for the parameters in $\gamma$ also to vary with $j$. Though this specification is more flexible, allowing the model to better capture the conditions of each local labor market, it also demands much more from the data, leading to estimates of the conditional racial wage gap that can be less precise in smaller microregions. Therefore, we use this specification only to assess the robustness of our benchmark results. 


\section{Second Stage}

The estimated racial wage gaps, $\hat{\delta}_{j t}$ 's, are used to construct the change in the racial wage gap over time for each local labor market $j: \Delta\left(\hat{\delta}_{j}\right)=\hat{\delta}_{j t}-\hat{\delta}_{j t-1}$. This variable becomes the dependent variable in our second stage regression, estimated by WLS:

$\Delta\left(\hat{\delta}_{j}\right)=\mu+\beta \Delta\left(\right.$ tariff $\left._{j}\right)+\lambda^{\prime} \boldsymbol{W}_{j}+\omega_{j}$

where $\Delta$ (tariff) represents the change in average tariffs between 1990 and 1995, $\boldsymbol{W}$ is a vector of controls, and $\omega$ is a random term. The controls included in the vector $\boldsymbol{W}$ capture changes in aggregate market conditions in the micro-regions, which might affect the determination of wages and, indirectly, the racial wage gap. We discuss the specific variables included later on in this section. Following Charles and Guryan (2008), the second stage regression is weighted by the precision of the first stage estimates (inverse of the standard-error of $\Delta\left(\hat{\delta}_{j}\right)$ ).

Our parameter of interest in the second stage is $\beta$, which captures the impact of the change in average tariffs on the conditional racial wage gap. The theory of taste-based discrimination presented in Section 2 predicts that increased competition in the market for final goods should lead to reductions in the conditional racial wage gap, so we should expect $\beta>0$. In other words, reductions in tariffs should be associated with reductions in the wage advantage that whites have in relation to blacks.

Our discussion on identification makes it clear that changes in tariffs were not driven by recent changes in local labor market conditions and, therefore, were not endogenous to the issue that we want to analyze here. Still, there remains the possibility that changes in tariffs might have affected the racial wage gap through channels other than that predicted by the theory of taste-based discrimination. This is the main concern in the estimation of our second stage and guides our choice of control variables to be included in $\boldsymbol{W}$.

One possibility in this direction comes from other labor market effects of trade liberalization. The Heckscher-Ohlin model predicts that, after liberalization, a country should shift its production towards goods intensive in its relatively abundant factor, leading to an increase in the relative return to this factor. From this perspective, in the case of Brazil, one should expect to see a shift in production towards sectors intensive in low skill labor, accompanied by a reduction in the wage differential between high and low skill workers. Our first stage specification already controls for 
schooling, partially accounting for the effects associated with changes in returns to productive attributes. Still, if one thinks that this same Heckscher-Ohlin effect should operate in relation to unobserved skills, it might be the case that it would interfere in the relationship between changes in tariffs and changes in racial wage gaps. This would be the case, for example, if blacks had access to education of lower (unobserved) quality, and liberalization also reduced wage differentials across (unobserved) qualities of education. For this to be the case, the change in returns to unobserved productive attributes (quality of schooling) would have to accompany the change in returns to observed productive attributes (years of schooling), and blacks would have to be less skilled than whites in terms of unobserved attributes.

To minimize this potential problem, we include as controls in our vector $\boldsymbol{W}$ the changes in average wages between 1991 and 2000 by level of schooling: up to 7 years (less than elementary), from 8 to 10 years (complete elementary and high-school drop-outs), from 11 to 14 years (complete high-school and college drop-outs), and 15 years or more (college graduates). By controlling for changes in returns to productive attributes, we are accounting for Heckscher-Ohlin effects in local labor markets. Even if we cannot measure returns to unobserved attributes, this strategy should go a long way towards shedding light on whether the issue discussed in the previous paragraph is a threat to identification. If changes in returns to unobserved attributes are driving the results, it must be the case that they are correlated with changes in returns to observed productive attributes. So, by controlling for the latter, we are capturing labor market equilibrium conditions associated with returns to different skill levels, and indeed partially controlling for the former. If the inclusion of these controls does not affect the coefficient of interest, it is because the correlation between reduction in tariffs and changes in the racial wage gap is not driven by changes in returns to productive attributes (observed or unobserved).

There was continuous improvement in schooling levels in Brazil during this period. So we also control directly for the change in the supply of workers by skill level and race, which might be associated with similar changes in the distribution of unobserved skills (and could be correlated, for example, to statistical discrimination). We include in $\boldsymbol{W}$ the share of workers by years of schooling and race, using the same educational classification discussed before. To control for other potential changes in educational policies, which might as well affect unobserved skills, we control for the change in the supply of public education. Since blacks are relatively poorer, increases in the quality of the public educational system may affect relatively more blacks than whites. We do not have a direct measure of the quality of the educational system for this period - such as results of 
standardized exams -, so we control for the change in the number of public schools normalized by the number of children.

Another potential effect of trade liberalization is through investments in technology. Juhn et al. (2013) find that NAFTA reduced the gender wage gap in Mexico not because of reduced discrimination, but because of investments in technology that reduced the demand for physical labor. Though this possibility seems less plausible in the context of races, we still account for it by including in our vector of controls $\boldsymbol{W}$ the share of blue collar workers in each micro-region. If there is some technological change in response to liberalization, one should expect it to be partly reflected on changes in the relative share of blue collar workers. We also control for unemployment and informality rates (among salaried workers), to account for other margins of labor market adjustment, and for migration, which might affect the response of local labor markets to exogenous shocks (as suggested by Cadena and Kovak, 2013). These labor market changes could have been affected by the trade reforms and could have heterogeneous effects across races. Additionally, they help control for broader patterns in the Brazilian labor market.

Our benchmark specification also includes dummies for the 5 main geographic regions in Brazil. In some specifications, we replace the 5 geographic region dummies by 27 state dummies.

\subsection{Calculating Average Tariffs for Local Labor Markets}

Trade policy in Brazil is determined at the federal level, so tariffs are the same for each sector irrespectively of location. But the structure of employment varies across locations, so the impact of a given reduction in tariff is not homogeneous across the territory. To take advantage of this fact and explore the differential impact of the trade reform across local labor markets with different initial structures, we follow Kovak (2013). Kovak (2013) proposes a methodology for calculating average tariffs for local labor markets based on a model specifically developed to analyze the regional impacts of trade liberalization. His model treats each region (local labor market) as a specific-factors economy with two inputs: labor and an immobile factor. Labor is supplied inelastically in each region and can move across sectors, but cannot migrate across regions. The immobile factor, which we call capital here, cannot move across sectors or across regions, and represents location specific factors that augment the productivity of labor in a given industry. ${ }^{3}$ Technology is assumed to have constant returns to scale and to vary across sectors, but not within sectors across regions. Finally, there is a single national market for the goods produced in the different regions.

3 These could include natural resources, land, agglomeration effects, and specific fixed capital, as suggested by Kovak (2013). 
This model justifies the use of a measure of tariffs at the subnational level that is similar to a formulation that was already present in the empirical literature (Topalova, 2010), but had no theoretical basis. Consider an economy with sectors $r=1, \ldots, R$, where $R$ represents the non-tradable sector. From the perspective of local labor market $j$, the relevant variation in tariffs between period $t-1$ and $t$ is

$\Delta\left(\operatorname{tariff} f_{j}\right)=\sum_{r \neq R} \psi_{j r}\left\{\ln \left(1+\operatorname{tariff}_{r t}\right)-\ln \left(1+\operatorname{tariff}_{r t-1}\right)\right\}$

where $\psi_{j r}=\frac{L_{j r} \epsilon_{j r}}{\sum_{r \neq R} L_{j r} \epsilon_{j r}}, L_{j r}$ indicates employment in sector $r$ in local labor market (micro-region) $j$, $\epsilon_{j r}=\frac{\sigma_{j r}}{\theta_{j r}}$ is the elasticity of the demand for labor, $\sigma_{j r}$ is the elasticity of substitution between inputs, and $\theta_{j r}$ is the share of capital in total cost.

In the model, the equilibrium change in local wages is proportional to this change in average tariffs. The change in average tariffs, in turn, captures the shock to local labor demand determined by the change in equilibrium prices due to trade liberalization. We use this same variable to analyze the impact of increased competition on labor market discrimination, with the understanding that the reduction in equilibrium prices following trade liberalization comes precisely from increased competition in the market for final goods and, therefore, is intrinsically associated with reduced average profits in the tradable sector.

The relevant change in tariffs faced by a local labor market is a weighted average of the changes in tariffs experienced by the different sectors, where the weights are functions of the elasticities of labor demand and employment levels observed in each sector. Notice that the nontradable sector is not explicitly considered in the weighted average, a result that comes directly from the theoretical model (in fact, according to the model, the relevant variation for the non-tradable sector is equivalent to the average variation across sectors). Since changes in employment and elasticities may be endogenous, only values from the initial period (1991) are considered in the calculation.

In practical terms, given the limited information available, some simplifying assumptions are needed. Following Kovak (2013), we assume that the technology is Cobb-Douglas, which implies a constant elasticity of substitution for every $j$ and $r: \sigma_{j r}=1$. Second, we assume that the share of capital in total cost $\left(\theta_{j r}\right)$ varies across sectors, but not across regions, so that $\theta_{j r}=\theta_{j}$. The value of each $\theta_{j}$ is calculated from the National Accounts as the fraction of value added not associated with 
labor earnings: $\theta_{r}=\frac{V A_{r}-L E_{r}}{V A_{r}}$, where $V A_{r}$ is the value added in sector $r$ and $L E_{r}$ indicates labor earnings in sector $r$. In fact, under these additional assumptions, the incorporation of the elasticity of demand in the calculation of average tariffs is of little consequence. ${ }^{4}$

When conducting our empirical exercises, we also test the robustness of our results to other commonly used measures of trade openness: the ratio of imports to production (M/P) and the import penetration coefficient (MPC, defined as MPC $\equiv$ Imports/(Production + Imports - Exports)). These data are only available by sectors at the national level. We use equation 8 and apply the same strategy used for tariffs to calculate M/P and MPC by micro-regions.

\section{Data}

\subsection{Sources of Data and Sample}

We use data from the Brazilian 1991 and 2000 censuses to estimate the conditional wage gaps in the first stage of our empirical strategy (equation 6). These data are also used to calculate the aggregate variables introduced as controls in the second stage (changes in aggregate labor market conditions, including average wages and employment by educational categories, shares of blue collar occupations, share of informal employees, unemployment, and migration). We define blue collar occupations as those that typically do not require formal (technical or college) training or education, as opposed to professional occupations. In the 1991 census, we define blue collar occupations as those associated with codes 301-928. These include, among various others, fishermen, miners, mechanics, shoemakers, bricklayers, merchandise packers, sellers, cashiers, drivers, cleaners, and dustmen. Informal employees are defined as those who do not have a registered labor contract (or, in terms of the Brazilian legislation, do not have their "labor card" signed by the employer). Regarding migration, census data allow us to calculate the percentage of the population that immigrated to a given micro-region within the previous five years.

We also use the change in the number of schools per capita as control in some specifications of our second stage. We construct this variable as the number of public schools (preschools, elementary schools, and high schools) per 1,000 individuals aged between 0 and 17 in each microregion (data from the Brazilian School Census). Unfortunately, there are no data for number of schools in 1991, so we use information from 1995 and 2000 to construct the change in this variable.

${ }^{4}$ Kovak (2013) reports a correlation of 0.996 between the results of calculations with and without the inclusion of $\epsilon_{j r}$. 
Tariff reductions are calculated from information provided by Kume et al. (2003). Kume et al. (2003) compute average tariffs for 32 sectors directly from international trade legislation. These 32 sectors are not entirely consistent with the sectorial classification used by the Brazilian census, so we merge some of them in order to make the two datasets compatible (Appendix Table A.2 describes how the two sectorial classifications were merged). This gives us 20 sectors plus services. The tariffs of the "new" merged sectors are calculated as weighted averages of their subsectors, where the weights are given by the relative value added of each subsector.

Value added and total labor earnings by sector, used to calculate the change in average tariffs by micro-region, are provided by the National Accounts from the Brazilian Census Bureau (IBGE). The National Accounts also provide the value of production needed to compute our alternative measures of exposure to trade (import-production ratio and import penetration coefficient). Import and export data are from Gonzaga et al. (2006), while data on market concentration in Brazil, used in some heterogeneity analyses, are from Ferreira and Fachini (2005).

As mentioned before, our benchmark specification uses the change in tariffs between 1990 and 1995, as Kovak (2013), because this period concentrates the part of the trade reform that effectively represented increased openness. Since we look at changes in wages between 1991 and 2000, we implicitly assume that: (i) the change in policy was perceived as permanent; (ii) the main labor market adjustments due to the trade reform were already completed by 2000; and (iii) the minor additional changes to trade legislation introduced after 1995 were not critical for labor market outcomes in 2000. We assess the validity of assumption (ii) by also looking at the long-run effect of the trade liberalization using the 2010 census. Assumptions (i) and (iii) are supported by the fact that there was little variation in tariffs after 1995, with long-term changes between 1990 and 2010 remaining highly correlated with those observed up to the moment immediately after liberalization in 1995 (correlation coefficient above 0.96 up to 2010 when looking at changes in average tariffs for local labor markets; see Dix-Carneiro et al., 2016). Still, in some robustness exercises, we also consider changes in tariffs from 1990 to 1998 and from 1987 to 1995.

Our main results use a sample of male employees (excluding public servants, self-employed, employers, and domestic workers), with positive earnings, aged between 20 and 60. We choose to focus on prime aged male employees to come closer to the concept of employer discrimination from Becker (1957), and to emulate the hypothesis of inelastic labor supply present in both Becker (1957) and Kovak (2013). Under these restrictions, there are 1.8 million observations in the 1991 census sample and 2.3 million observations in the 2000 census sample. To assess the robustness of the 
results to potential market imperfections associated with labor market attachment, insertion, and mobility, some alternative samples are also considered. For example, we present results including self-employed men, women, and restricting the sample to full-time workers.

Finally, in the second stage of our analysis, the unit of observation is a micro-region, taken to represent a local labor market. We use compatible definitions of micro-regions in the 1991 and 2000 censuses, resulting in a total of 480 observations. ${ }^{5}$

\subsection{Descriptive Analysis}

Table 1 presents descriptive statistics for the 1991 and 2000 censuses, based on our main sample (male employees between ages 20 and 60, with positive earnings). In addition to providing a broad overview of the labor market conditions in Brazil during the period of our analysis, the table also helps guide our later discussion of the results.

The typical individual in the sample in both years has around 34 years of age, works full time (more than 90\%), did not complete elementary school, works in the services sector, and in a blue collar occupation. It is worth noticing the reduction of 7 percentage points in the fraction of workers with less than complete elementary education between 1991 and 2000, the increase in the fraction of workers attending school, and the reduction in the share of workers in manufacture. Real wages are approximately stable during the period, driven mostly by the change in the composition of the labor force, since wages fell for most educational levels (with the exception of college, which comprises a small fraction of the population; real wages in 2000 values, deflated by the National Consumer Price Index, following Corseuil and Foguel, 2002).

The last rows in the table present numbers on the trade variables used and on the conditional racial wage gap. ${ }^{6}$ The average tariff reduction across micro-regions was 9.7 percentage points (corresponding to $48 \%$ of the initial level), and was accompanied by increases of $85 \%$ in the ratio of imports to production and $81 \%$ in the import penetration coefficient. The seemingly small initial level of tariffs when looking at micro-region averages, when compared to Figure 2 for example, comes from the role of the agricultural sector. ${ }^{7}$ Tariffs were already low in agriculture by 1990 and,

\footnotetext{
${ }^{5}$ Appendix B describes the procedure adopted to make the definition of micro-regions compatible across censuses. This procedure leads to an initial sample of 488 micro-regions. We lose 8 micro-regions due to missing observations on some of the key variables (for example, the smallest micro-regions do not have observations for employees with positive wages for certain combinations of race and educational group). We use the 480 observations with a complete set of variables throughout to keep a consistent sample in all empirical exercises. Results are very similar if, where possible, we use the complete sample of 488 observations.

${ }^{6}$ The conditional racial wage gap in the table is the average of the gaps estimated for each micro-region in our first stage. ${ }^{7}$ Appendix Table A.1 presents the sectorial distribution of employment in the Brazilian economy for 1991. As mentioned before, the 1991 sectorial shares are used as weights in the calculation of average tariff changes by micro-region.
} 
excluding the services sector, agriculture employed a substantial fraction of the labor force. The combination of these two facts dampens the sectorial tariff reductions discussed before. Nevertheless, the reduction in tariffs represented a substantial change in exposure to foreign competition, which indeed ended up reflected on the measures of import penetration.

It is also important to notice that the conditional racial wage gap remained roughly stable in Brazil during this period (in fact, it was reduced by 0.4 percentage point). So, if trade liberalization did work towards reducing labor market discrimination, other factors must have worked in the opposite direction. An answer to this specific question is beyond the scope of this paper. Still, it highlights the fact that we are exploring the role of increased competition in reducing the racial wage gap in a context where there is no widespread trend in this direction.

\section{Results}

We concentrate on the results from the second stage, since our first stage reproduces commonly used estimation procedures for Mincer regressions. Still, when useful, we briefly mention the specification used to estimate the racial wage gap in the first stage.

Table 2 presents the main result from our empirical exercise. Column 1 shows the coefficient of a univariate regression of the change in the conditional racial wage gap on the change in tariffs, without additional controls. Column 2 introduces dummies for geographic regions, corresponding to the five great geographic regions in Brazil: North, Northeast, Center-West, Southeast, and South. Column 3 adds controls for changes in earnings by level of schooling (primary, elementary, high school, and college), and column 4 replaces the geographic region dummies with state dummies (26 states plus the Federal District). Panel A corresponds to our benchmark specification, where a single Mincer regression is used to estimate the racial wage gap for all micro-regions in a given year, while Panel B corresponds to an alternative specification where a different Mincer regression is estimated separately for each micro-region in each year.

Column 1 in Panel A shows that there is a positive correlation between changes in tariffs and changes in the conditional racial wage gap, as predicted by theory. This means that local labor markets that experienced larger reductions in average tariffs also experienced larger reductions in the conditional wage differential across races (remember that our race dummy indicates white workers). The introduction of regional dummies in column 2 increases slightly the magnitude and the precision of the estimated coefficient. 
The most important result from Table 2 is the change in the coefficient of interest once we move from column 2 to column 3. In column 3, we control for changes in wages by levels of schooling, which should account for the effects of trade on local labor markets that would emerge from a Heckscher-Ohlin model. By controlling for these variables, we are accounting for the relative change in demand for skills driven by shifts in production towards sectors intensive in the abundant factor (in the case of Brazil, low skill labor). If the positive and significant coefficient on $\Delta$ (tariff) in columns 1 and 2 were only capturing a relative increase in the demand for unskilled labor - with blacks being less skilled than whites - one should expect to see a reduction in the estimated coefficient as we move from column 2 to column 3. Notice that this should be the case even if the coefficients estimated in columns 1 and 2 were related to unobserved skills, as long as the change in returns to unobserved skills followed the same pattern of the change in returns to observed skills (meaning that locations with reduced wage differentials across observed skills also displayed reduced wage differentials across unobserved skills). But once we control for changes in earnings by level of schooling, the coefficient of interest increases in magnitude and remains strongly significant. The correlation between changes in tariffs and changes in racial wage gaps captured by our empirical strategy does not seem to be driven by changes in returns to productive attributes (in addition, our first stage already controls for schooling and allows for changes in the return to schooling between 1991 and 2000). ${ }^{8}$ This conclusion is further reinforced by the fact that there is no consensus in the literature on the effect of trade liberalization on returns to skill in Brazil (see, for example, Arbache and Menezes-Filho, 2000, Arbache and Courseuil, 2004, Gonzaga et al., 2006, Ferreira et al., 2010, Kovak, 2013, Dix-Carneiro and Kovak, 2015). ${ }^{9}$

\footnotetext{
${ }^{8}$ Notice that the coefficient on the change in primary schooling wages is negative and statistically significant. This is consistent with the argument made in the text that increases in the relative gains of low skill workers in terms of observed attributes (in the case of Brazil, primary educated workers, in which blacks are overrepresented) should be correlated with relative gains to low skill workers also in terms of unobserved attributes, which should in turn be correlated with reductions in the conditional racial wage gap. This effect can be seen in the significant and negative coefficient on the change in primary wages in column 3. Still, this is not driving the estimated impact of the change in tariffs and, therefore, does not interfere with our identification strategy.

${ }^{9}$ For the interested reader, Appendix Table A.3 repeats the same specification from column 3 of Table 2 by educational levels. It shows that, even when estimated separately for each level of schooling, we still find positive and statistically significant coefficients for the cases of primary and elementary schooling. Coefficients are estimated much less precisely for high school and college education, since the number of first stage observations for these cases is very small in various micro-regions. In this exercise, we re-estimate the conditional racial wage gap in the first stage by interacting the racial dummy with the dummies for years of schooling. The second stage remains the same as before. If we include selfemployed workers in our first stage, increasing the size of the sample and the precision of the estimates, results for all schooling levels become positive and statistically significant (results available upon request). So the results in the last two columns of Table A.3 seem indeed to be driven by the low number of first stage observations and imprecision in the estimation of the conditional racial wage gap.
} 
In column 4, we replace the 5 geographic region dummies by 27 state dummies. The estimated impact of the change in tariffs increases slightly in magnitude, but remains very similar to that from column 3. Specific characteristics of regions or states do not seem to be correlated with our estimated coefficient. Since we have an average of only 18 micro-regions per state, the specification with state dummies becomes too heavy and compromises the precision of the estimates in some of our following empirical exercises, where we look at more restrictive samples. We proceed therefore with the controls from column 3, including geographic region dummies, as our benchmark specification. ${ }^{10}$

Panel B in Table 2 reproduces the same sequence of results from Panel A, but using a separate Mincer regression in the first stage to estimate the conditional racial wage gap in each micro-region and year. ${ }^{11}$ This strategy is more flexible in that it allows for returns to productive attributes - such as education or experience - to vary across micro-regions in the same year, therefore better capturing the specific characteristics of the equilibrium in each local labor market. On the other hand, it demands much more from the data. Results in Panel B are very similar in magnitude and significance to those in Panel A. In addition, the qualitative pattern of change in coefficients as we move from columns 1 to 4 remains the same, so the discussion related to Panel A applies here as well. ${ }^{12}$

According to the Hecksher-Ohlin model, relative returns to inputs should summarize all the relevant impacts of trade reforms on labor markets, so the benchmark specification from Table 2 is the closest in spirit to the theory. But we check the robustness of our results to other labor market changes that could be important in the presence of market imperfections and that, in principle, might have differential effects across races. Some of these may be functions of the phenomenon we are analyzing here and may not strictly belong to the right-hand side of our estimating equation (see

${ }^{10}$ Results are virtually identical as well if we control for informality when estimating the wage regression in the first stage (see Appendix Table A.4). Informality might be a concern in terms of interpretation of the results if changes in wages were entirely driven by changes in informality at the individual level, and informality were intrinsically associated with race.

11 The equation estimated for each micro-region $j$ and year $t$ is: $\ln (\text { wage })_{i j t}=\alpha_{j t}+\delta_{j t}$ white $_{i j t}+\gamma_{j t}{ }^{\prime} \boldsymbol{Z}_{i j t}+\varepsilon_{i j t}$, where the vector $\boldsymbol{Z}$ includes all variables included in $\boldsymbol{X}$, with the exception of the micro-region dummies.

12 Appendix Table A.5 presents yet an additional alternative specification, where we estimate the impact of the reduction in tariffs directly, in one single step, together with the Mincerian equation. In this strategy, we estimate a single Mincerian regression including both years and adding year and micro-region dummies. Akin to a difference-in-difference strategy, the effect of the tariff reduction on the gender wage gap is identified, in this case, from the interaction of the micro-region specific tariff (which changes between years) with the race dummy (indicating white). To come as close as possible to our two-stage strategy, we include the same individual and aggregate (micro-region) level controls used in our previous first and second stages, and let the coefficients on the individual level variables vary across years. Table A.5 reproduces, in this setting, specifications analogous to those from Tables 2 and 3. Estimated coefficients are again positive and statistically significant, being typically very similar to the corresponding coefficients presented in Tables 2 and 3 . 
discussion in Angrist and Pischke, 2009). Still, keeping this limitation in mind, we believe they help shed light on the driving forces behind the results reported before. Specifically, one may wonder whether the magnitude and significance of the estimated impact of the reduction in tariffs is in some way correlated with the changes observed along these dimensions. If they are not, there would be further support to the idea that we are indeed capturing the effect of increased competition in the market for final goods on labor market discrimination. So we incorporate these additional variables in Table 3, but do not carry them over to other specifications in the paper. ${ }^{13}$

Column 1 in Table 3 includes controls for the shares of employment by level of schooling and race (where the excluded category is primary schooling). Column 2 , instead, controls for the number of public schools per 1,000 children. Column 3 controls for labor market changes associated with occupational structure (share of blue collar occupations), informality, and unemployment. Finally, column 4 adds the control for immigration and column 5 includes all previous controls simultaneously.

In columns 1, 3, and 4 of Table 3, results are very close to those from Table 2 . In column 2 , the coefficient is slightly smaller in magnitude, but remains strongly significant. Most importantly, when all controls are included simultaneously in column 5 , the coefficient is again very similar to that estimated in column 3 of Table 2 and remains statistically significant.

Concerns related to changes in schooling or access to education, to other labor market consequences of the trade reform, to migration, or to broader macroeconomic trends - which in principle might have heterogeneous impacts across races due to non-observable productive attributes - do not seem to be first order issues. Some of these dimensions did affect the racial wage gap during the 1991-2000 period, but in ways that are on average orthogonal to the relationship between competition in the market for final goods and labor market discrimination. Notice, in particular, that Table 3 rules out alternative explanations based on changes in statistical discrimination due to differential changes in access to schooling across races (which, by chance, could be correlated with the reductions in tariffs). As long as these were correlated to education, one would expect the controls in column 1, which have virtually no impact on the estimated coefficient, to account for this type of effect.

Our benchmark specification (column 3 in Table 2) implies that a reduction in average local tariffs of 9.7 percentage points (equivalent to the average observed in the sample) leads to a

\footnotetext{
${ }^{13}$ In any case, the vast majority of qualitative results reported in other tables in the paper remain unchanged under any of the other specifications from Table 2. These results are available from the authors upon request.
} 
reduction of 2.2 percentage points in the conditional racial wage gap (or 18\% of its 1991 value, which was 12.3). Alternatively, a reduction in tariffs corresponding to one standard-deviation in the initial period (7 percentage points in 1991) would lead to a reduction of $13 \%$ in the racial wage gap. Though this effect may not seem particularly large, one should bear in mind that over the 1991-2000 period there was hardly any reduction at all in the conditional racial wage gap (0.4 percentage point). In other words, according to our estimates, had the liberalization process not taken place, the conditional racial wage gap would have increased by 1.8 percentage points (abstracting from aggregate effects of the trade liberalization on the racial wage gap, which are not captured by our identification strategy). Increased competition may have reversed a widening of the racial wage gap that would otherwise have been observed.

It is also worth noting that the impact of increased competition on the racial wage gap documented in Table 2 summarizes almost in its entirety the effects observed in the long-run. Appendix Table A.6 presents the results from a regression that reproduces our same benchmark exercise looking at the 1991 and 2010 censuses (instead of 1991 and 2000). The coefficients estimated for this extended 20-year period are very similar in magnitude to - and statistically indistinguishable from - those in Table 2. The evidence indicates that the trade liberalization led to a reduction in labor market discrimination due to increased competition that persisted over time.

\subsection{Alternative Timing and Measures of Trade Liberalization}

Our first robustness exercise considers alternative timings and measures of trade liberalization. The benchmark specification uses changes in tariffs between 1990 and 1995, corresponding to the period of effective liberalization. One might think that this would exaggerate the extent of liberalization, possibly biasing our estimates. To address this concern, we consider alternative specifications that use the change in tariffs between 1990 and 1998 (the last year for which consolidated data on tariffs by sector are computed by Kume et al., 2003), and between 1987 and 1995.14 The results are presented in columns 1 and 2 of Table 4 . In column 1, the estimated coefficient remains almost identical to that in Table 2 (column 3). In column 2, it increases in magnitude and remains strongly significant. So the specific timing of measurement of the change in tariffs does not seem to interfere with the results.

Other concern related to the measurement of the reforms refers to the use of tariffs as sufficient statistics for trade liberalization. Various other dimensions of economic policy and

14 To calculate average tariffs for the merged sectors (see section 5.1) in 1998, we use value added from the 1995 National Accounts, and, for 1987, we use value added from the 1985 National Accounts. 
regulation affect the effective degree of protection in a given economy, including non-trade barriers, exchange rate regimes, and red tape. For these reasons, some consider that variables related to the flow of international trade are more adequate measures of the actual degree of openness in an economy. In fact, Brazil experienced changes in exchange rate regimes during the 1990s as well as successive elimination and reintroduction of non-tariff barriers. This concern may therefore be indeed relevant. In addition, as argued by Gonzaga et al. (2006), the pass through of tariff changes to prices may vary across sectors. Still, trade flows are endogenous to economic and labor market conditions.

In any case, we also consider alternative measures of exposure to foreign competition based on trade flows: the ratio of imports to production (M/P) and the import penetration coefficient (MPC). The results obtained when these are used as independent variables are presented in columns 3 and 4 in Table 4. It is worth remembering that, contrary to tariffs, increases in these variables indicate increased exposure to international trade. So the prediction of the theory is that these two variables should be negatively associated with changes in the racial wage gap (increased exposure to international trade associated with reduced advantages of whites in the labor market).

As predicted by theory, and consistent with the results for tariffs, both measures of trade flows indicate that increased imports during the period of trade reforms were associated with reductions in the conditional racial wage gap. The coefficients in columns 3 and 4 are negative and statistically significant. Though the scales of the three independent variables are different and, therefore, estimated coefficients cannot be directly compared to one another, their quantitative implications in normalized units are very similar. An increase in M/P corresponding to one standard-deviation in the initial period (0.011 in 1991) would be associated with a reduction of $12 \%$ in the conditional racial wage gap, a result identical to that obtained with the MPC variable and very close to the $13 \%$ mentioned before for tariffs. In other words, the specific variable used to represent the process of trade liberalization does not affect the results either qualitative or quantitatively.

\subsection{Pre-trends and Falsification Exercises}

The timing of the reforms and the measures of exposure to trade based on flows also provide us with an opportunity to falsify our identification strategy. First, we account for pre-trends by controlling for the change in the racial wage gap before the trade reform (between 1980 and 1991). Since there was a different political organization of Brazil in 1980, we have 284 micro-regions in this analysis (micro-regions were aggregated to be made compatible across 1980 and 1991, and there were fewer municipalities and micro-regions in 1980 than in 1991; see Appendix B for details). For 
purposes of comparison, we first estimate again the specification from column 3 in Table 2 using data from 1991 and 2000 with this new geographic division including 284 micro-regions. Results are shown in column 1 of Panel A from Table 5. As shown in column 1, results remain positive and statistically significant, increasing slightly in magnitude. So the different definition of micro regions does not substantially affect the results obtained before. In columns 2 , 3, and 4 we estimate our benchmark specification with the three alternative measures of trade liberalization controlling for pre-existing trends (the change in the racial wage gap between 1980 and 1991). Results remain very similar, both in terms of significance and magnitude.

Another falsification exercise that allows us to assess whether pre-existing trends seem to be a problem is to test if the change in the racial wage gap between 1980 and 1991 was correlated with (future) changes in exposure to foreign competition between 1990 and 1995. If the trade reform was truly exogenous to changes in local labor market conditions, one should expect such regression to yield non-significant results. Otherwise, if the change in exposure to trade in the 1990s was associated with labor market trends before that date - which might have continued into the future this regression might yield significant results.

Columns 1, 2, and 3 in Panel B from Table 5 show the results from these regressions, where the change in the wage gap between 1980 and 1991 is regressed on our three measures of change in exposure to foreign competition between 1990 and 1995. All estimated coefficients are very small in magnitude and far from statistically significant. Pre-existing trends indeed do not seem to be a concern in our empirical exercise.

Finally, we can perform an additional placebo exercise to reinforce the role that the natural experiment represented by the 1990s trade reform plays in our identification strategy. If our identification strategy is indeed capturing the effect of the trade reform from the 1990s, we should find no significant result once we repeat an analogous exercise using data from 1980 and 1991, since there was no major change in trade protection during this period. Otherwise, if we are just capturing some spurious correlation between changes in imports and changes in labor market outcomes, we should also find a significant effect when looking at data between 1980 and 1991. Though we do not have changes in tariffs by sector for the 1980s (Kume et al., 2003 do not compute these numbers and, besides, there were few changes between 1980 and 1990), we do have data on imports, exports, and production.

Columns 4 and 5 in Panel B from Table 5 reproduce the same exercise from Table 2, but comparing data from the 1980 and 1991 censuses and using the two measures of exposure to trade 
that we have for 1980 and 1990 (M/P and MPC). Both estimated coefficients are small in magnitude and far from statistically significant. There is no indication of a spurious correlation between changes in international trade and changes in the racial wage gap before the reforms were implemented. This evidence suggests that the reduction in the racial wage gap in response to tariff reductions (or increases in imports) documented in Panel A is indeed associated with the shock represented by the process of trade liberalization from the 1990s.

In this section, we provided evidence supporting the key identifying assumption underlying the use of our natural experiment. No other paper in the literature on competition and labor market discrimination was able to validate its empirical strategy in a similar fashion.

\subsection{Alternative Samples}

The results presented up to now use a sample of male employees, aged between 20 and 60, with positive earnings. This brings the empirical exercise closer to the theory of taste-based employer discrimination (Becker, 1957), but may call into question the representativeness of the results for the Brazilian labor market as a whole. Our results would still be representative of the overall impact of increased competition under the assumption of perfect labor mobility across labor market insertion statuses within regions. With imperfect labor mobility and differential entry and exit, on the other hand, the impact of increased competition on wages may be heterogeneous across groups of workers. To assess this possibility, we re-estimate our first stage with different samples. The results from these exercises are presented in Table 6.

The following sample variations are considered in the first stage, always restricting to individuals between 20 and 60 years of age: in column 1, all male workers; in column 2, all male and female workers; in column 3, all male and female employees and self-employed; in column 4, all male and female employees; and, in column 5, all male employees not attending school, and working full-time (at least 35 hours per week).

Results in column 1, where we look at all men, are larger in magnitude than those from Table 2 and still significant. This is consistent with part of the labor market adjustments after the reform taking place through differential transition of workers across occupational categories (most importantly, between employees and self-employed). As we move to columns 2 and 3, considering all men and women and then employees and self-employed, the coefficient is reduced a bit in magnitude in comparison to column 1, but remains strongly significant. When we consider only male and female employees, in column 4, the coefficient drops in magnitude, but still remains statistically significant. Finally, in column 5, we consider only men who do not attend school and are employed 
full-time, coming closer to the hypothesis of inelastic labor supply from both Becker (1957) and Kovak (2013). Results rise again in magnitude and remain statistically significant.

Differences in sample across genders, labor market insertion, and labor market attachment do not seem to affect the qualitative results. This pattern suggests a reasonable degree of flexibility in local labor markets in Brazil, which is supported by evidence of a high degree of mobility across the formal and informal sectors (see, for example, review in Ulyssea, 2006). For all samples considered, we detect a significant impact - mostly of similar magnitude - of increased competition on labor market discrimination.

\subsection{Heterogeneity}

An additional possibility to shed further light on the mechanism behind the estimated effect of increased competition on labor market discrimination is to explore some dimensions of heterogeneity predicted by Becker's (1957) theory. As discussed in Section 2, the model of tastebased employer discrimination predicts that some characteristics of local labor markets should be associated with higher initial levels of discrimination and, therefore, with larger responses of discrimination to reductions in tariffs. First, the model demonstrates that discrimination requires the existence of pure economic rents. So labor markets dominated by firms that face low competition in the market for final goods should respond more to liberalization than markets dominated by firms that face more competition. Second, for given market structure and distribution of tastes for discrimination, markets with a larger share of minority workers should display initially higher levels of discrimination. Finally, locations with stronger prejudice against the minority - strictly, with a marginal employer with a higher coefficient of discrimination - should also be associated with more discrimination in the labor market.

We explore these three dimensions to assess whether there is heterogeneity in the initial level of the racial wage gap and in the impact of increased liberalization on the wage gap, and whether this heterogeneity supports the predictions of the theory. The relationship between market concentration, in particular, and discrimination has received some recent attention in the theoretical literature. Ederington and Sandford (2013) develop a dynamic monopolistic competition model with firm entry and exit and show that the response of labor market discrimination to increased competition in the market for final goods should be unequivocally stronger in more concentrated markets, even within their much richer framework. Our natural experiment presents a particularly appealing setting to test this relationship. These patterns would be hard to rationalize outside the 
taste-based discrimination theory, if, for example, one still suspects that the coefficients estimated before may be partly capturing statistical discrimination or returns to unobserved skills.

In order to measure the degree of monopoly power in the market for final goods, we follow Ferreira and Fachini (2005) and use the four-firm concentration ratio (CR4), which considers a sector to be concentrated if the share of the four largest firms in total revenue is above $40 \%{ }^{15}$ We use the classification of concentrated sectors from Ferreira and Fachini (2005) and, to translate it to the level of local labor markets, calculate the share of workers occupied in concentrated sectors by micro-region. Following, we use the fraction of black workers in 1991 (black and mixed) as indicating the share of the minority in the local labor market. To measure the strength of tastes for discrimination, we use the index based on inter-racial marriages proposed by Levine et al. (2008), also constructed from the 1991 census. The index captures unobserved factors associated with the frequency of inter-racial marriages in a given micro-region (netted out of effects of education, age, and racial composition of the population), ${ }^{16}$ with higher values indicating higher discrimination. The basic idea is that, conditional on observables, locations with a higher incidence of inter-racial marriages should have a lower underlying level of prejudice against the minority. ${ }^{17}$ In order to make the coefficients more easily interpretable and comparable, we standardize the three variables (subtract the mean and divide by the standard deviation).

Panel A in Table 7 starts by showing the results of simple micro-region OLS regressions for 1991, where the conditional racial wage gap is regressed on the three local labor market characteristics - market concentration, percentage of black workers, and the prejudice index - plus geographic region dummies. As predicted by theory, the three variables are positively related to the initial level of labor market discrimination, either when considered separately (columns 1 to 3) or jointly (column 4). All coefficients are positive and statistically significant, indicating that higher market concentration, higher share of the minority in the labor force, and higher average prejudice

\footnotetext{
15 Ferreira e Fachini (2005) classify as concentrated the following sectors in 1985: transportation, rubber, chemicals, perfumery, and tobacco. The authors do not analyze extractive sectors. Since petroleum, natural gas, and charcoal are monopolies or concessions, they are also considered concentrated.

${ }^{16}$ Specifically, we estimate an OLS regression for couples, where the dependent variable is a dummy indicating an interracial marriage, and the independent variables are age, age squared, dummies for years of schooling, share of blacks in the micro-region, share of blacks squared, a dummy for urban areas, and state dummies. The average residual for a micro-region, $q_{j}$, indicates the component of the probability of an inter-racial marriage in micro-region $j$ that is not explained by socio-demographic factors. To renormalize it as an index where higher values are associated with higher discrimination, we define $q_{j}^{\prime}=\max _{i}\left(q_{i}\right)-q_{j}$. This is the measure of tastes for discrimination that we use in our analysis.

17 Becker's (1957) theory predicts that the coefficient of discrimination of the marginal employer, not the average coefficient of discrimination, should determine the observed racial wage gap. We do not have a measure of the distribution of preferences for discrimination by micro-region, simply a proxy for its average. We proceed under the assumption that shifts in this average would be typically associated with shifts in the entire distribution of preferences for discrimination.
} 
are all positively correlated with observed labor market discrimination. The distribution of the racial wage gap in the cross-section is consistent with the theory of taste-based discrimination.

In Panel B of Table 7, we incorporate heterogeneity along these three dimensions in our main empirical exercise. First, in separate second stage regressions, we include interactions of the change in tariffs with these three variables, one at a time. Columns 1 to 3 present these results. For the case of market concentration (column 1), the coefficient is positive and statistically significant. Microregions with higher market concentration in 1991 experienced larger declines in the racial wage gap following the trade reform from the 1990s.

The coefficient on the fraction of black workers (column 2), in turn, is very small quantitatively - negative - and far from statistically significant. There seems to be no clear pattern in the case of the share of the minority in the labor force. This may be due to the possibility that the racial mix in a certain region can end up directly affecting preferences and social norms in the longrun, something not considered in Becker's (1957) framework.

For the prejudice index (column 3), the coefficient is positive, but also estimated very imprecisely. This imprecise estimate may be related to the fact that the adequate measure of prejudice according to theory should be the coefficient of discrimination of the marginal employer, while our measure is a proxy for the average coefficient of discrimination in the population. The evidence presented in Charles and Guryan (2008) suggests that this distinction can have non-trivial consequences when testing the model of taste-based employer discrimination.

In column 4 of Panel $\mathrm{B}$, we consider a specification including the three dimensions of heterogeneity simultaneously. In line with the pattern from columns 1 to 3 , we estimate a positive and significant coefficient on the interaction of the change in tariffs with market concentration, and a positive but imprecisely estimated coefficient on the interaction with the prejudice index. As before, the coefficient on the interaction with the fraction of blacks is non-significant, but now appears as positive. Though the three interactions appear, as expected, with positive coefficients when included together, the coefficients on the fraction of blacks and the prejudice index are very small and imprecisely estimated.

Given the limitations of some of the variables used, we read the results from Table 7 as providing evidence that certain dimensions of heterogeneity predicted by the employer discrimination model are present in the data. The cross-sectional distribution of the conditional racial wage gap is consistent with the theory. In addition, the estimates indicate that higher market concentration is associated with a stronger impact of increased exposure to competition on labor 
market discrimination. A higher fraction of blacks and a higher prejudice index, when considered together, are also positively correlated with a stronger impact of liberalization, but very mildly and not significantly in statistical terms. These results agree with the predictions of the theory of tastebased employer discrimination along dimensions that are otherwise difficult to rationalize. The heterogeneity according to market concentration, in particular, which has been subject to more thorough theoretical analysis, is clearly present in the data.

\section{Concluding Remarks}

We use the episode of trade liberalization in Brazil during the 1990s to test the effect of increased competition in the market for final goods on discrimination in the labor market. We show that local labor markets that experienced relatively higher exposure to international competition due to trade liberalization also observed relatively larger reductions in the conditional wage differential between white and black workers. As predicted by the theory of taste-based discrimination, the initial racial wage gap and the impact of increased competition were larger in local labor markets dominated by firms in more concentrated sectors.

Our empirical setting delivers a clean identification of the effect of increased competition in the market for final goods on labor market discrimination - and provides direct evidence validating the identification hypothesis -, therefore improving upon the existing literature. Our results also incidentally imply that labor market discrimination due to racial prejudice is a prevalent phenomenon even in the case of Brazil, a highly mixed country often regarded as racially integrated. By exploring the issue of wage differentials across races, our paper also speaks to the broader literature on trade liberalization and inequality, and identifies a specific dimension over which increased openness contributed to reduce earnings inequality. Increased competition does appear as an important determinant of labor market discrimination, and policies that foster competition are therefore likely to be potentially important tools to fight racial discrimination in the marketplace.

\section{References}

Anderson, E. Openness and Inequality in Developing Countries: A Review of Theory and Recent Evidence (2005). World Development, 33(7), 1045-63.

Angrist, J. D.; Pischke, J. S. (2009). Mostly Harmless Econometrics: An Empiricist's Companion. Princeton University Press, 392 p. 
Arbache, J. S.; Corseuil, C. H. (2004). Liberalização comercial e estruturas de emprego e salário. Revista Brasileira de Economia, 58(4), 485-505.

Arbache, J. S.; Menezes-Filho, N. A. (2000). Rent-sharing in Brazil: using trade liberalization as a natural experiment. Rio de Janeiro: Annals of the $V$ Annual Meeting of the Latin American and Caribbean Economic Association.

Artecona, R.; Cunningham, W. (2002). "Effects of Trade Liberalization on the Gender Wage Gap in Mexico." World Bank Policy Research Report on Gender and Development, Working Paper 21.

Ashenfelter, 0.; Hannan, T (1986). Sex discrimination and product market competition: The case of the banking industry. Quarterly Journal of Economics, 101(1), 149-73.

Becker, G. (1957). The economics of discrimination. University of Chicago Press, 167p.

Berik, G.; Van Der Meulen Rodgers, Y.; Zveglich, J. (2004). International Trade and Gender Wage Discrimination: Evidence from East Asia. Review of Development Economics, 8(2), 237-54.

Black, S. E.; Brainerd, E. (2004). Importing equality? The impact of globalization on gender discrimination. Industrial and Labor Relations Review, 57(4), 540-559.

Black, S. E.; Strahan, P. E. (2001). The division of spoils: rent-sharing and discrimination in a regulated industry. American Economic Review, 91(4), 814-831.

Cadena, B. C.; Kovak, B. K. (2013). "Immigrants Equilibrate Local Labor Markets: Evidence from the Great Recession.” Unpublished manuscript, Carnegie Mellon Univesity.

Charles, K.; Guryan, J. (2008). Prejudice and wages: an empirical assessment of Becker's "The economics of discrimination." Journal of Political Economy, 116(5), 773-809.

Corseuil, C. H.; Foguel, M. N. (2002). "Uma sugestão de deflatores para rendas obtidas a partir de algumas pesquisas domiciliares do IBGE." IPEA, Working Paper 897.

De Loecker, J.; Goldberg, P. K.; Khandelwal, A. K.; Pavcnik, N. (2016). Prices, Markups and Trade Reform. Econometrica, forthcoming.

Dix-Carneiro, R. (2012). "Trade Reform and Reallocation: What have we learned and what is next?" Unpublished manuscript, University of Maryland.

Dix-Carneiro, R.; Kovak, B. K. (2014). "Trade Reform and Regional Dynamics: Evidence From 25 Years of Brazilian Matched Employer-Employee Data" Unpublished manuscript,

Dix-Carneiro, R.; Kovak, B. K. (2015). Trade Liberalization and the Skill Premium: A Local Labor Markets Approach. American Economic Review - Papers and Proceedings, 105(5), 551-557.

Dix-Carneiro, R.; Soares, R. R.; Ulyssea, G. (2016). “Local Labor Market Conditions and Crime: Evidence from the Brazilian Trade Liberalization." IZA Discussion Paper 9638.

Edmond, C.; Midrigan, V.; Xu, D. Y. (2015). Competition, Markups, and the Gains from International Trade. American Economic Review, 105(10), 3183-3221.

Ederington, J.; Sandford; J. (2013). "Employer discrimination and market structure: Does more concentration mean more discrimination?" Unpublished manuscript, University of Kentucky.

Ferreira, F.; Leite, P. G.; Poi, M. W. (2010). "Trade Liberalization, Employment Flows and Wage Inequality in Brazil." World Bank, Policy Research Working Paper.

Ferreira, P. C.; Facchini, G. (2005). Trade liberalization and industrial concentration: Evidence from Brazil. The Quarterly Review of Economics and Finance, 45(2), 432-446. 
Goldberg, P. K.; Pavcnik, N. (2007). Distributional effects of globalization in developing countries. Journal of Economic Literature, 45(1), 39-82.

Gonzaga, G.; Menezes-Filho, N.; Terra, C. (2006). Trade liberalization and the evolution of skill earnings differentials in Brazil. Journal of International Economics, 68(2), 345-367.

Hellerstein, J.; Neumark, D.; Troske, K. (2002). Market forces and sex discrimination. Journal of Human Resources, 37(2),353-380.

Jacob, M (2006). "The Impact of Trade Liberalization on Gender and Caste Groups in India." PhD Dissertation, University of Maryland.

Juhn, C.; Ujhelyi, G.; Villegas-Sanchez, C. (2013). Trade liberalization and gender inequality. American Economic Review - AEA Papers and Proceedings, 103(3), 269-273.

Kawaguchi, D. (2007). A market test for sex discrimination: Evidence from Japanese firm level data. International Journal of Industrial Organization, 25(3), 441-460.

Kovak, B. K. (2013). Regional effects of trade reform: What is the correct measure of liberalization? American Economic Review, 103(5), 1960-76.

Kume, H.; Piani, G.; Souza, C. F. B. (2003). A política brasileira de importação no período 1987-98: descrição e avaliação. In: Corseuil, C. H. and Kume, H. (eds). A Abertura Comercial Brasileira nos Anos 1990: Impactos sobre Emprego e Salário. IPEA, Rio de Janeiro, 9-37.

Levine, R.; Levkov, A.; Rubinstein, Y. (2008). Racial Discrimination and Competition. NBER Working Paper 14273.

Lu, Y.; Yu, L. (2015). Trade Liberalization and Markup Dispersion: Evidence from China's WTO Accession. American Economic Journal: Applied Economics, 7(4), 221-253.

Oostendorp, R. H. (2009). Globalization and the Gender Wage Gap. World Bank Economic Review, 23(1), 141-61.

Peoples, J.; Talley, W. K. (2001). Black-white earnings differentials: privatization versus deregulation. American Economic Review, 91(2), 164-168.

Reis, E. J.; Pimentel, M.; Alvarenga, A. I.; Horácio, M. C. (2011). Áreas mínimas comparáveis para os períodos intercensitários de 1872 a 2000. Anais do I Simpósio Brasileiro de Cartografia Histórica. Paraty.

Theodoro, M. (2008). As Políticas Públicas e a Desigualdade Racial no Brasil 120 Anos após a Abolição. Ipea, Brasília, 176p.

Topalova, P. (2010). Factor immobility and regional impacts of trade liberalization: Evidence on poverty from India. American Economic Journal: Applied Economics, 2(4), 1-41.

Ulyssea, G. (2006). Informalidade no mercado de trabalho brasileiro: uma resenha da literatura. Revista de Economia Política, v.26, 4(104), 596-618.

Wolszczak-Derlacz, J. (2013). Mind the Gender Wage Gap-the Impact of Trade and Competition on Sectoral Wage Differences. The World Economy, 36(4), 437-464.

Zweimüller, M.; Winter-Ebmer, R.; Weichselbaumer, D. (2008). Market orientation and gender wage gaps: An international study. Kyklos, 61(4), 615-635. 
Figure 1: Comparative Statics in the Taste Based Model of Employer Discrimination

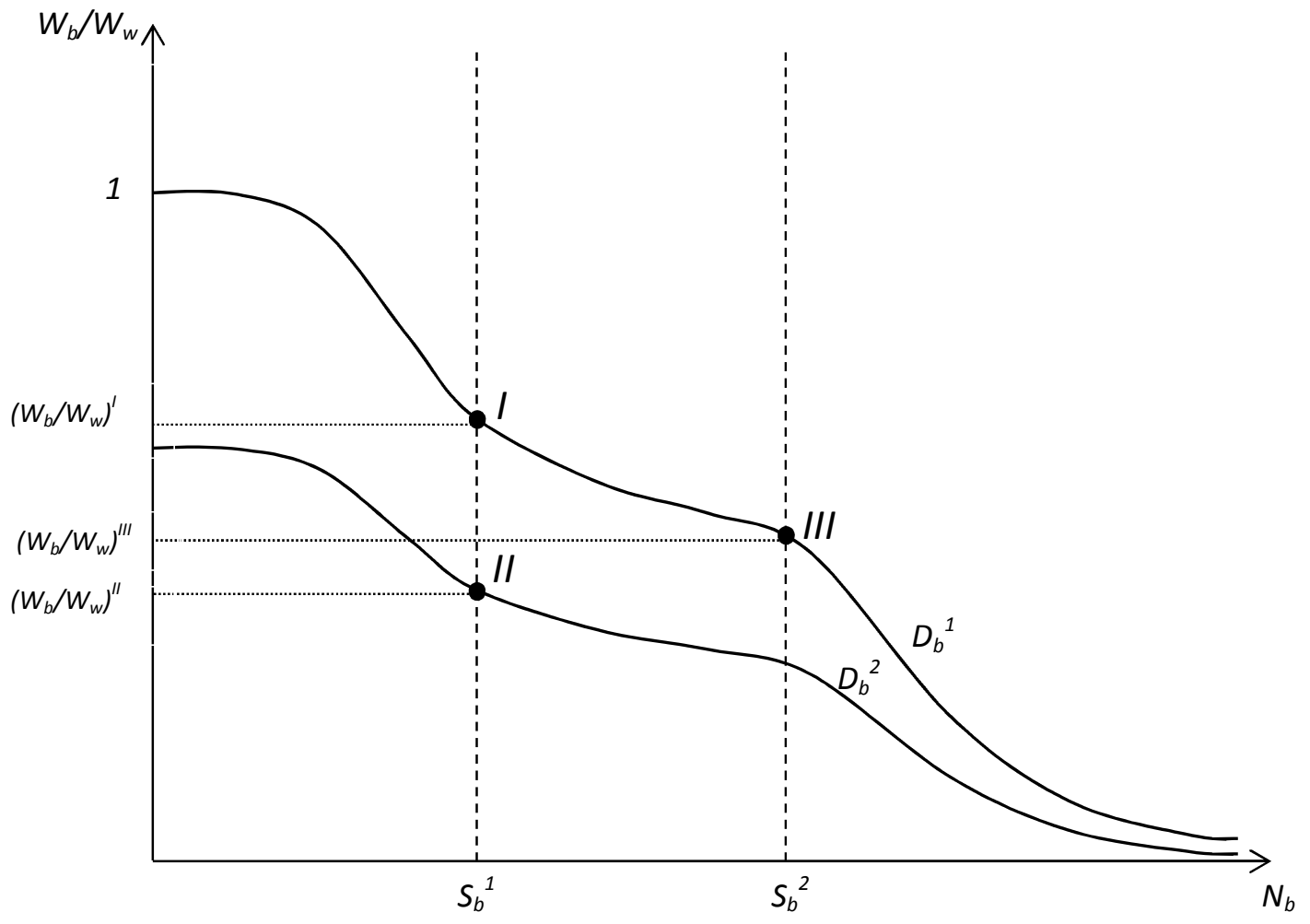


Figure 2: Nominal Import Tariffs during the Late 1980s and 1990s, Brazil

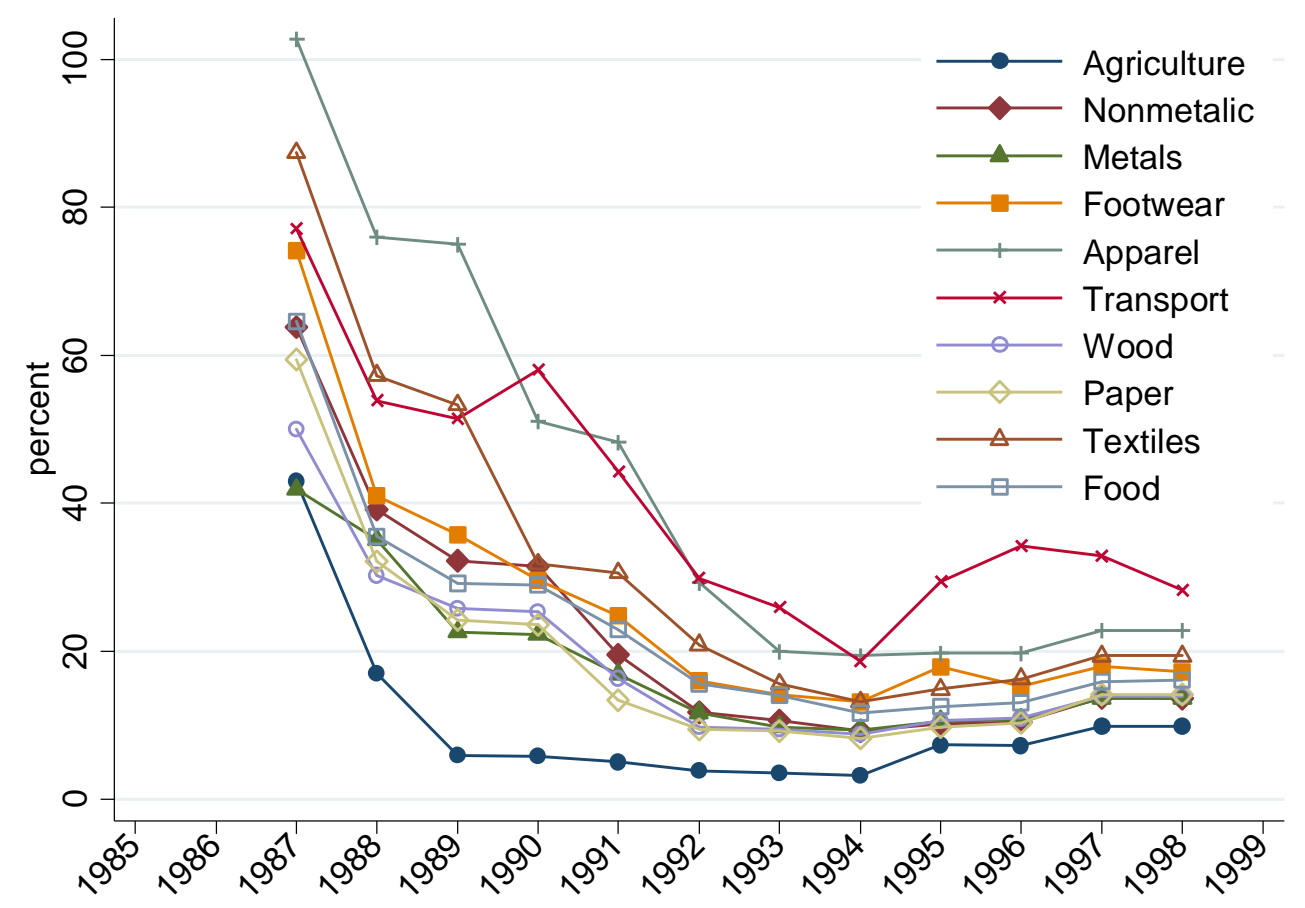

Source: Data from Kume et al. (2003). 
Figure 3: Imports during the Late 1980s and 1990s, Brazil (1985 value normalized to 1)

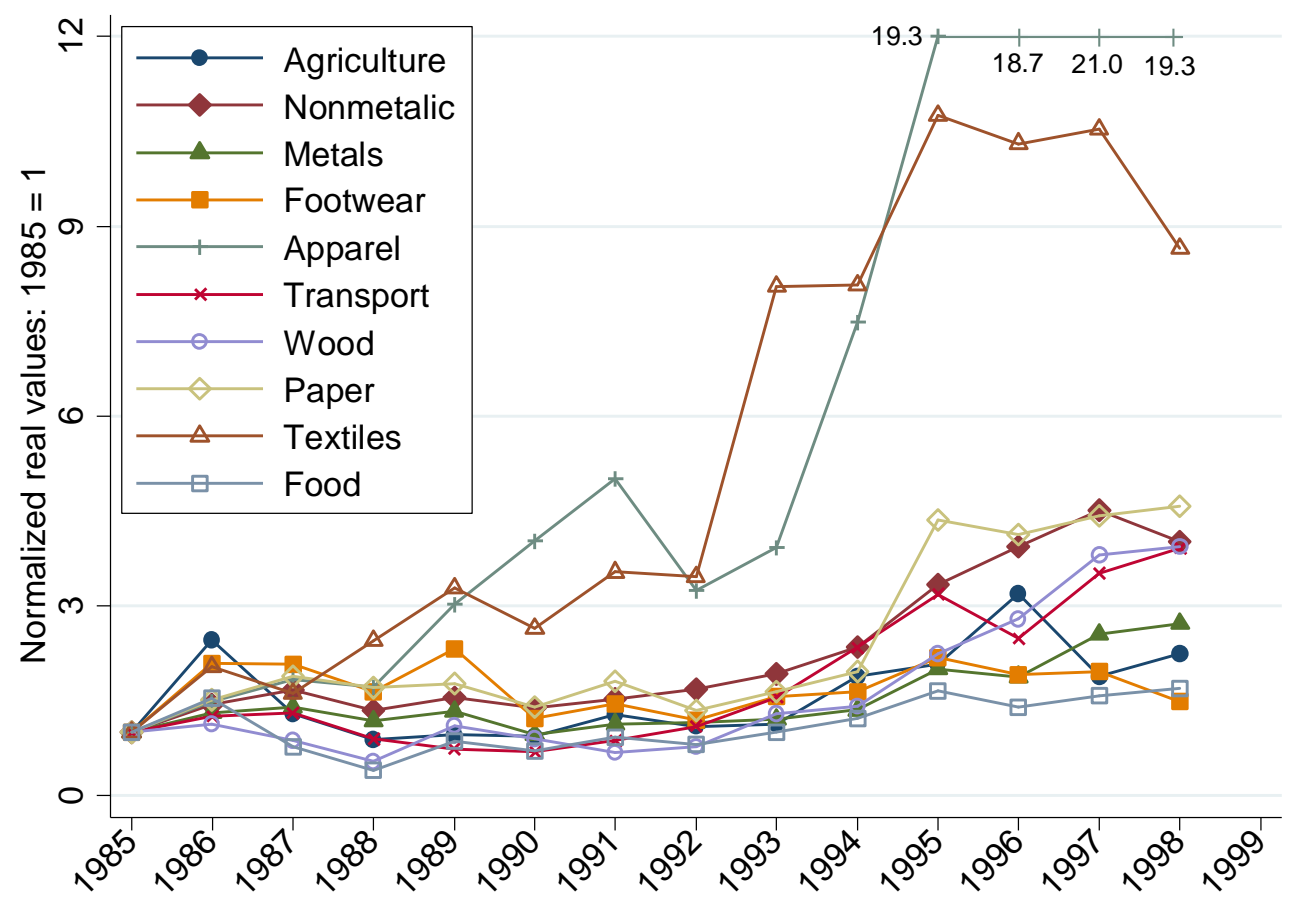

Source: Data from Gonzaga et al. (2006). 
Figure 4: Tariff Reductions between 1990 and 1995 and Initial Tariff Levels in 1990 by Sector of Economic Activity, Brazil

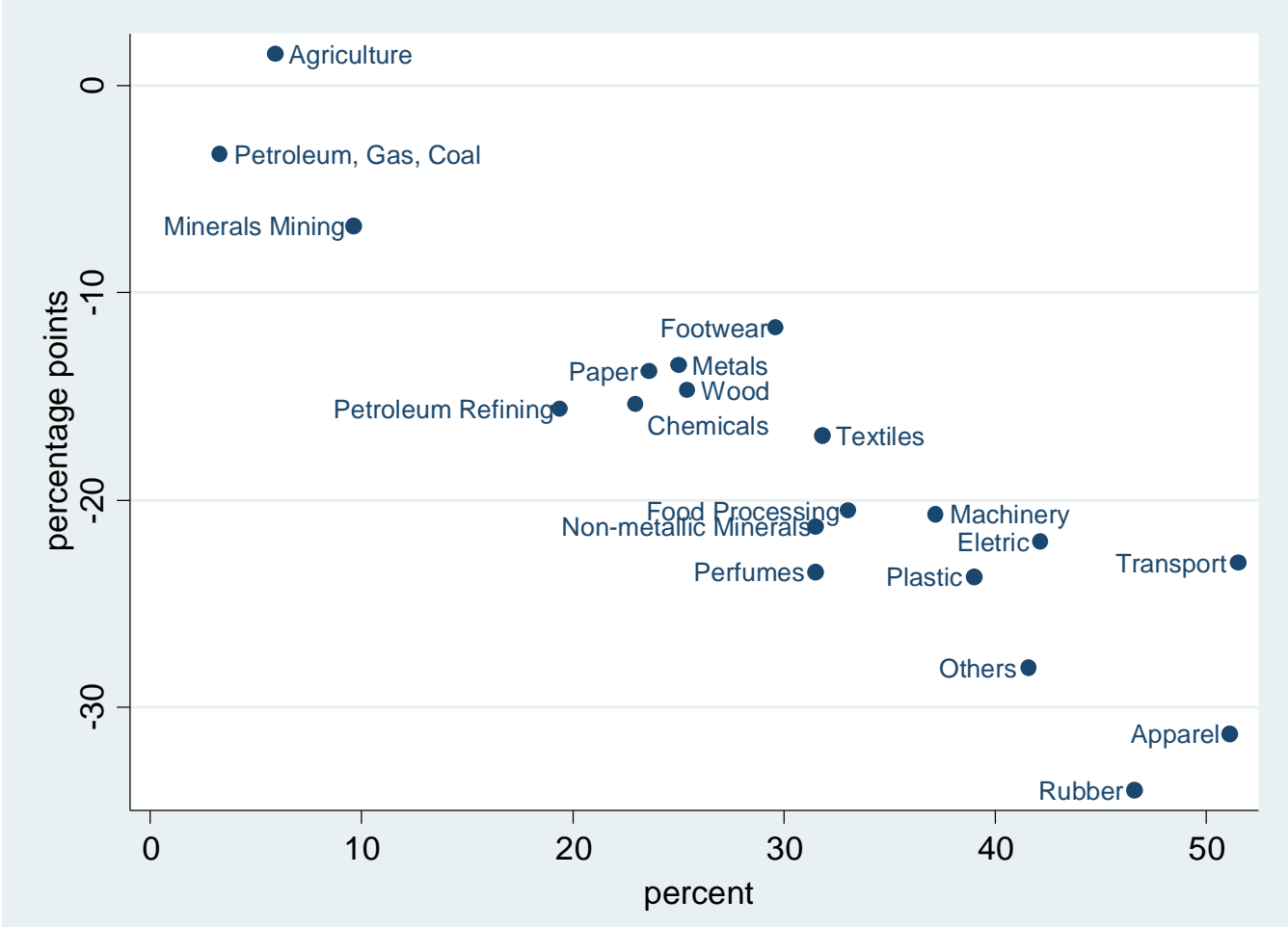

Source: Data from Kume et al. (2003). 
Figure 5: Tariff Reductions between 1990 and 1995 and Initial Tariff Levels in 1990 by Micro-Region, Brazil

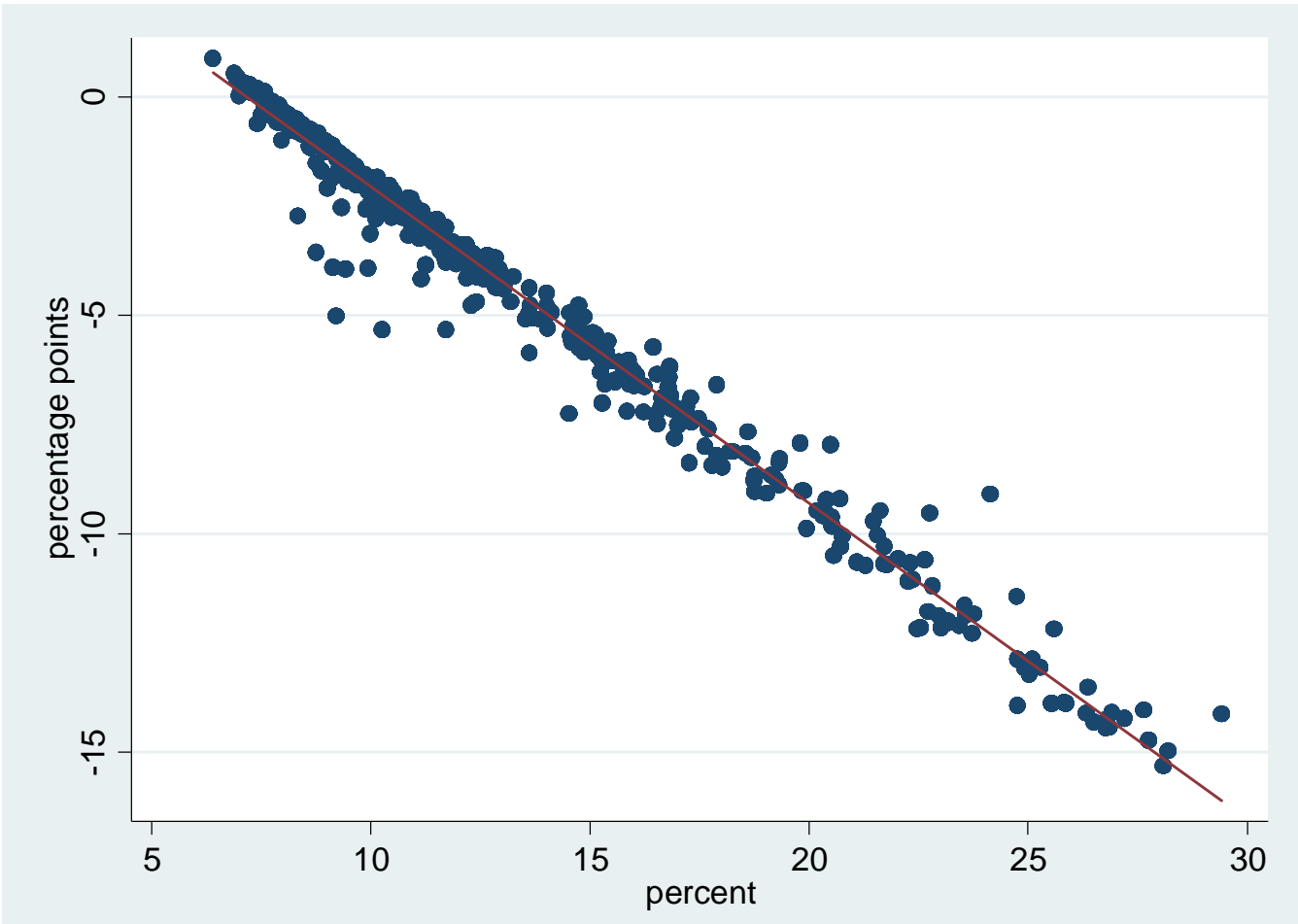

Source: Authors' calculations based on data from the 1991 census and from Kume et al. (2003). 
Table 1: Descriptive Statistics, Brazil, 1991 and 2000, Male Employees, ages 20-60

\begin{tabular}{|c|c|c|c|c|}
\hline & \multicolumn{2}{|c|}{1991} & \multicolumn{2}{|c|}{2000} \\
\hline & Mean & s.d. & Mean & s.d. \\
\hline Black & 0.445 & 0.497 & 0.451 & 0.498 \\
\hline Age & 33.7 & 10.0 & 34.1 & 10.2 \\
\hline Full-time Work (35 hours/week or more) & 0.945 & 0.227 & 0.928 & 0.258 \\
\hline Migrant & 0.105 & 0.306 & 0.087 & 0.282 \\
\hline Attend school & 0.045 & 0.207 & 0.091 & 0.288 \\
\hline Primary School (up to 7 years of schooling) & 0.621 & 0.485 & 0.551 & 0.497 \\
\hline Elementary School ( 8 to 10 years of schooling) & 0.154 & 0.361 & 0.175 & 0.38 \\
\hline $\begin{array}{l}\text { High School ( } 11 \text { to } 14 \text { years of schooling) } \\
\text { College/University (above } 15 \text { vears of }\end{array}$ & 0.163 & 0.369 & 0.216 & 0.412 \\
\hline schooling) & 0.062 & 0.242 & 0.058 & 0.234 \\
\hline Blue collar & 0.786 & 0.41 & 0.816 & 0.388 \\
\hline Informal & 0.196 & 0.397 & 0.332 & 0.471 \\
\hline Agriculture & 0.116 & 0.32 & 0.148 & 0.355 \\
\hline Mineral Mining & 0.016 & 0.127 & 0.008 & 0.089 \\
\hline Manufacture & 0.278 & 0.448 & 0.208 & 0.406 \\
\hline Services & 0.59 & 0.492 & 0.636 & 0.481 \\
\hline Wage per hour $(\mathrm{R} \$)$ & 3.37 & 6.41 & 3.29 & 7.29 \\
\hline Wage per hour - Primary School & 1.92 & 3.18 & 1.80 & 3.14 \\
\hline Wage per hour - Elementary School & 3.09 & 4.39 & 2.73 & 4.15 \\
\hline Wage per hour - High School & 5.29 & 6.81 & 4.62 & 7.56 \\
\hline Wage per hour - College/University & 13.52 & 16.04 & 14.34 & 20.23 \\
\hline Observations (millions) & 1.8 & & 2.3 & \\
\hline \multicolumn{5}{|l|}{ Local Market Characteristics ${ }^{*}$} \\
\hline Mean tariff ${ }^{* *}$ & 0.202 & 0.07 & 0.105 & 0.021 \\
\hline Imports/Product $(\mathrm{M} / \mathrm{P})^{* *}$ & 0.026 & 0.011 & 0.048 & 0.023 \\
\hline Import Penetration Coefficient (MPC) ${ }^{* *}$ & 0.027 & 0.011 & 0.049 & 0.022 \\
\hline White-Black conditional wage gap ${ }^{* * *}$ & 0.123 & 0.072 & 0.119 & 0.052 \\
\hline
\end{tabular}


Table 2: Impact of Tariff Change on Racial Wage Gap, Brazilian Micro-regions, 1991-2000 Dependent Variable: Change in Conditional Racial Wage Gap

\begin{tabular}{|c|c|c|c|c|}
\hline & $(1)$ & $(2)$ & (3) & $(4)$ \\
\hline \multicolumn{5}{|c|}{ Panel A: One Regression in the First Stage } \\
\hline$\Delta($ tariff $)$ & $\begin{array}{l}0.133^{*} \\
(0.069)\end{array}$ & $\begin{array}{c}0.157^{* *} \\
(0.072)\end{array}$ & $\begin{array}{c}0.222^{* * *} \\
(0.066)\end{array}$ & $\begin{array}{c}0.242^{* * *} \\
(0.067)\end{array}$ \\
\hline$\Delta($ primary wage $)$ & & & $\begin{array}{c}-0.166^{* * *} \\
(0.030)\end{array}$ & $\begin{array}{c}-0.147^{* * *} \\
(0.035)\end{array}$ \\
\hline$\Delta($ elementary wage $)$ & & & $\begin{array}{c}0.041 \\
(0.035)\end{array}$ & $\begin{array}{c}0.033 \\
(0.036)\end{array}$ \\
\hline$\Delta$ (high school wage) & & & $\begin{array}{c}0.035 \\
(0.027)\end{array}$ & $\begin{array}{c}0.057^{* *} \\
(0.029)\end{array}$ \\
\hline$\Delta($ college wage $)$ & & & $\begin{array}{c}0.008 \\
(0.012)\end{array}$ & $\begin{array}{c}0.011 \\
(0.012)\end{array}$ \\
\hline Region Dummies & & $\mathrm{X}$ & $\mathrm{X}$ & \\
\hline State Dummies & & & & $\mathrm{X}$ \\
\hline Observations & 480 & 480 & 480 & 480 \\
\hline R-Squared & 0.008 & 0.044 & 0.110 & 0.165 \\
\hline
\end{tabular}

Panel B: Regressions by Micro-region in the First Stage
$\Delta($ tariff $)$
$0.114^{* *}$
$0.190^{* * *}$
$0.218^{* * *}$
$0.228^{* * *}$
$(0.048)$
$(0.051)$
$(0.051)$
$(0.047)$

$\Delta$ Avg W by Schooling Region Dummies

$\begin{array}{lll} & X & X \\ X & X & \\ & & \end{array}$

State Dummies

$\begin{array}{lcccc}\text { Observations } & 480 & 480 & 480 & 480 \\ \text { R-Squared } & 0.017 & 0.101 & 0.122 & 0.178\end{array}$

Notes: Robust standard errors in parentheses. ${ }^{* * *} \mathrm{p}<0.01 ;{ }^{* *} \mathrm{p}<0.05,{ }^{*} \mathrm{p}<0.10$. Panel A first stage is a regression for 20-60 year-old male employees. First stage independent variables in Panel A: age, age squared, dummies for years of schooling, urban area, and micro-region, and interactions between a dummy for white and micro-region dummies. Panel B first stage is a set of independent regressions, estimated separately for each micro-region. First stage independent variables in Panel B: age, age squared, dummies for years of schooling and urban area, and dummy for white. Second stage independent variables: region and state dummies (not shown), and changes in micro-region average wages by level of schooling (primary, elementary, high school, and college). Unit of observation is a micro-region. Census data from 1991 and 2000. Regressions weighted by the precision of first-stage estimates of the dependent variable (inverse of the standard errors). 
Table 3: Additional Controls, Impact of Tariff Change on Racial Wage Gap, Brazilian Microregions, 1991-2000 - Dependent Variable: Change in Conditional Racial Wage Gap

\begin{tabular}{|c|c|c|c|c|c|}
\hline & $(1)$ & $(2)$ & $(3)$ & $(4)$ & $(5)$ \\
\hline$\Delta($ tariff $)$ & $\begin{array}{c}0.244^{* * *} \\
(0.083)\end{array}$ & $\begin{array}{c}0.178^{* * *} \\
(0.067)\end{array}$ & $\begin{array}{c}0.223^{* * *} * \\
(0.071)\end{array}$ & $\begin{array}{c}0.245^{* * *} \\
(0.066)\end{array}$ & $\begin{array}{c}0.215^{* *} \\
(0.086)\end{array}$ \\
\hline$\Delta(\% \text { elementary })_{\text {blacks }}$ & $\begin{array}{c}0.288^{* *} \\
(0.141)\end{array}$ & & & & $\begin{array}{l}0.262^{*} \\
(0.142)\end{array}$ \\
\hline$\Delta(\% \text { high school })_{\text {blacks }}$ & $\begin{array}{c}0.071 \\
(0.151)\end{array}$ & & & & $\begin{array}{c}0.053 \\
(0.146)\end{array}$ \\
\hline$\Delta(\% \text { college })_{\text {blacks }}$ & $\begin{array}{l}0.656 \\
(0.538)\end{array}$ & & & & $\begin{array}{c}0.649 \\
(0.551)\end{array}$ \\
\hline$\Delta(\% \text { elementary })_{\text {whites }}$ & $\begin{array}{l}-0.013 \\
(0.179)\end{array}$ & & & & $\begin{array}{l}-0.058 \\
(0.181)\end{array}$ \\
\hline$\Delta(\% \text { high school })_{\text {whites }}$ & $\begin{array}{l}-0.119 \\
(0.134)\end{array}$ & & & & $\begin{array}{l}-0.159 \\
(0.135)\end{array}$ \\
\hline$\Delta(\% \text { college })_{\text {whites }}$ & $\begin{array}{c}0.207 \\
(0.285)\end{array}$ & & & & $\begin{array}{l}0.088 \\
(0.287)\end{array}$ \\
\hline $\begin{array}{l}\Delta(\# \quad \text { schools } / 1,000 \\
\text { children })\end{array}$ & & $\begin{array}{c}-0.010^{* *} \\
(0.004)\end{array}$ & & & $\begin{array}{l}-0.008^{*} \\
(0.004)\end{array}$ \\
\hline$\Delta(\%$ blue collar $)$ & & & $\begin{array}{c}0.120 \\
(0.208)\end{array}$ & & $\begin{array}{c}0.123 \\
(0.212)\end{array}$ \\
\hline$\Delta(\%$ informal $)$ & & & $\begin{array}{c}-0.172^{* * *} \\
(0.055)\end{array}$ & & $\begin{array}{c}-0.135^{* *} \\
(0.058)\end{array}$ \\
\hline$\Delta(\%$ unemployed $)$ & & & $\begin{array}{l}-0.118 \\
(0.135)\end{array}$ & & $\begin{array}{l}-0.025 \\
(0.147)\end{array}$ \\
\hline$\Delta(\%$ migrant $)$ & & & & $\begin{array}{l}-0.185 \\
(0.157)\end{array}$ & $\begin{array}{l}-0.069 \\
(0.150)\end{array}$ \\
\hline$\Delta$ Avg W by Schooling & $\mathrm{X}$ & $\mathrm{X}$ & $\mathrm{X}$ & $\mathrm{X}$ & $\mathrm{X}$ \\
\hline Region Dummies & $\mathrm{X}$ & $\mathrm{X}$ & $\mathrm{X}$ & $\mathrm{X}$ & $\mathrm{X}$ \\
\hline Observations & 480 & 480 & 480 & 480 & 480 \\
\hline R-Squared & 0.126 & 0.120 & 0.134 & 0.114 & 0.151 \\
\hline
\end{tabular}


Table 4: Impact of Alternative Measures of Trade Liberalization on Racial Wage Gap, Brazilian Micro-regions, 1991-2000 - Dependent Variable: Change in Conditional Racial Wage Gap

\begin{tabular}{|c|c|c|c|c|}
\hline Indep. Var.: & $\begin{array}{c}\Delta(\text { tariff })_{1990-1998} \\
(1)\end{array}$ & $\Delta(\text { tariff })_{(2)}{ }_{1987-1995}$ & $\begin{array}{c}\Delta(\mathrm{M} / \mathrm{P})_{1990-1995} \\
(3)\end{array}$ & $\begin{array}{c}\Delta(\mathrm{MPC})_{1990-1995} \\
(4)\end{array}$ \\
\hline Coefficient & $\begin{array}{c}0.234^{* * *} \\
(0.066)\end{array}$ & $\begin{array}{c}0.318^{* * *} \\
(0.119)\end{array}$ & $\begin{array}{c}-1.331^{* * *} \\
(0.265)\end{array}$ & $\begin{array}{c}-1.369^{* * *} \\
(0.278)\end{array}$ \\
\hline Observations & 480 & 480 & 480 & 480 \\
\hline R-Squared & 0.112 & 0.104 & 0.127 & 0.126 \\
\hline \multicolumn{5}{|c|}{$\begin{array}{l}\text { Notes: Robust standard errors in parentheses. }{ }^{* *} \mathrm{p}<0.01 ;{ }^{* *} \mathrm{p}<0.05,{ }^{*} \mathrm{p}<0.10 \text {. Independent variables: region dummies and } \\
\text { changes in average wages by level of schooling (not shown). Columns } 3 \text { and } 4 \text { use, respectively, the share of imports and the } \\
\text { import penetration coefficient as measures of the trade reform, instead of tariffs. Unit of observation is a micro-region. Census } \\
\text { data from } 1991 \text { and } 2000 \text {. Regressions weighted by the precision of first-stage estimates of the dependent variable (inverse of } \\
\text { the standard errors). First stage is a regression for } 20-60 \text { year-old male employees. First stage independent variables: age, age } \\
\text { squared, dummies for years of schooling, urban area, and micro-region, and interactions between a dummy for white and micro- } \\
\text { region dummies. }\end{array}$} \\
\hline
\end{tabular}


Table 5: Pre-trends and Falsification Exercises, Impact of Tariff Change on Racial Wage Gap, Brazilian 1980 Micro-regions, 1980-1991 - Dependent Variable: Change in Conditional Racial Wage Gap

Panel A: Controlling for Pre-Trends - Dep. Var.: $\Delta$ (w gap) $)_{1991-2000}$

\begin{tabular}{l|cccc}
\hline Indep. Var.: & $\Delta$ (tariff $)$ & $\Delta($ tariff $)$ & $\Delta(\mathrm{M} / \mathrm{P})$ & $\Delta(\mathrm{MPC})$ \\
& $(1)$ & $(2)$ & $(3)$ & $(4)$ \\
\hline \multirow{3}{*}{ Coefficient } & $0.297^{* * *}$ & $0.246^{* * *}$ & $-1.247^{* * *}$ & $-1.282^{* * *}$ \\
& $(0.066)$ & $(0.053)$ & $(0.226)$ & $(0.237)$ \\
& & & & \\
$\Delta(\text { w gap })_{1980-1991}$ & & $-0.593^{* * *}$ & $-0.587^{* * *}$ & $-0.587^{* * *}$ \\
& & $(0.067)$ & $(0.067)$ & $(0.066)$ \\
Obs. & 284 & 284 & 284 & 284 \\
R-Squared & 0.222 & 0.496 & 0.509 & 0.507 \\
\hline
\end{tabular}

Panel B: Placebo with Pre-Reform Period - Dep. Var.: $\Delta(\text { w gap })_{1980-1991}$

Indep. Var.:

1990-1995

1980-1990

\begin{tabular}{l|ccc|cc}
\hline & $\Delta$ (tariff) & $\Delta(\mathrm{M} / \mathrm{P})$ & $\Delta(\mathrm{MPC})$ & $\Delta(\mathrm{M} / \mathrm{P})$ & $\Delta(\mathrm{MPC})$ \\
& $(1)$ & $(2)$ & $(3)$ & $(4)$ & $(5)$ \\
Coefficient & & & & & \\
& -0.032 & 0.128 & 0.159 & -0.021 & -0.207 \\
& $(0.062)$ & $(0.221)$ & $(0.248)$ & $(0.106)$ & $(0.553)$ \\
Obs. & & & & & \\
R-Squared & 284 & 284 & 284 & 284 & 284 \\
\hline
\end{tabular}

Notes: Robust standard errors in parentheses. ${ }^{* * *} \mathrm{p}<0.01 ;{ }^{* *} \mathrm{p}<0.05,{ }^{*} \mathrm{p}<0.10$. Independent variables: region dummies and changes in average wages by level of schooling (not shown). Unit of observation is a micro-region, according to the 1980 definition. Census data from 1980, 1991, and 2000. Regressions weighted by the precision of first-stage estimates of the dependent variable (inverse of the standard errors). First stage is a regression for 20-60 year-old male employees. First stage independent variables: age, age squared, dummies for years of schooling, urban area, and micro-region, and interactions between a dummy for white and micro-region dummies. In Panel A, dependent variable is the change in the wage gap between 1991 and 2000, and the change in the wage gap between 1980 and 1991 is included as an additional control for pretrends. In Panel B, dependent variable is the change in the wage gap between 1980 and 1991. 
Table 6: Alternative Samples in the $1^{\text {st }}$ Stage, Impact of Tariff Change on Racial Wage Gap, Brazilian Micro-regions, 1991-2000 - Dependent Variable: Change in Conditional Racial Wage Gap

\begin{tabular}{|c|c|c|c|c|c|}
\hline & $\begin{array}{l}\text { Men } \\
(1)\end{array}$ & $\begin{array}{c}\text { Men \& } \\
\text { Women } \\
(2)\end{array}$ & $\begin{array}{c}\text { Employees } \\
\& \\
\text { Self-empl. } \\
(3) \\
\end{array}$ & $\begin{array}{c}\text { Employees } \\
(4)\end{array}$ & $\begin{array}{c}\text { Men, } \\
\text { Not in School, } \\
\text { Full-time } \\
(5)\end{array}$ \\
\hline$\Delta($ tariff $)$ & $\begin{array}{c}0.367^{* * *} \\
(0.064)\end{array}$ & $\begin{array}{c}0.295^{* * *} \\
(0.055)\end{array}$ & $\begin{array}{c}0.317^{* * * *} \\
(0.057)\end{array}$ & $\begin{array}{c}0.187^{* * *} \\
(0.061)\end{array}$ & $\begin{array}{c}0.334^{* * *} \\
(0.063)\end{array}$ \\
\hline Observations & 480 & 480 & 480 & 480 & 480 \\
\hline R-Squared & 0.193 & 0.269 & 0.209 & 0.219 & 0.173 \\
\hline 1991 w gap & 0.151 & 0.151 & 0.133 & 0.127 & 0.149 \\
\hline$\Delta$ (w gap) & 0.006 & -0.001 & 0.004 & -0.008 & 0.006 \\
\hline
\end{tabular}


Table 7: Heterogeneity of the Initial Wage Gap and of the Impact of Tariff Changes, Brazilian Micro-regions, 1991-2000 - Dependent Variable: 1991 Conditional Racial Wage Gap in Panel A and Change in Conditional Racial Wage Gap in Panel B

\begin{tabular}{lcccc}
\hline \multicolumn{1}{c}{$(1)$} & $(2)$ & $(3)$ & $(4)$ \\
\hline Panel A: Initial Wage Gap and Local Labor Market Characteristics & $(1991)$ \\
Market Concentration & $\begin{array}{c}0.012^{* * *} \\
(0.004)\end{array}$ & & & $0.014^{* * *}$ \\
& & & & $(0.004)$ \\
\% Black & & $\left(0.019^{* *}\right.$ & & $0.024^{* * *}$ \\
& & & $0.015^{* * *}$ & $0.016^{* * *}$ \\
Prejudice Index & & & $(0.004)$ & $(0.004)$ \\
& $\mathrm{X}$ & $\mathrm{X}$ & $\mathrm{X}$ & $\mathrm{X}$ \\
Region Dummies & & & & \\
Observations & 480 & 480 & 480 & 480 \\
R-squared & 0.065 & 0.050 & 0.066 & 0.126 \\
\hline
\end{tabular}

Panel B: Heterogeneity of the Impact of Tariff Change on Racial Wage Gap
$\Delta($ tariff $)$
$\begin{array}{cccc}0.158^{* *} & 0.241^{* * *} & 0.218^{* * *} & 0.171^{* *} \\ (0.074) & (0.069) & (0.065) & (0.074)\end{array}$
$0.171^{* *}$
$\Delta($ tariff $) \times$ Market Concentration
$0.180^{* * *}$
$0.173^{* * *}$
$(0.058)$
(0.056)
$\Delta($ tariff $) \times \%$ Black
$-0.035$
0.013
$(0.083)$
$\Delta($ tariff $) \times$ Prejudice Index
$\begin{array}{cc}0.033 & 0.019 \\ (0.093) & (0.088)\end{array}$

$\Delta$ Avg W by Schooling

Region Dummies

$\begin{array}{ll}\mathrm{X} & \mathrm{X} \\ \mathrm{X} & \mathrm{X}\end{array}$

$\mathrm{X}$
$\mathrm{X}$

$\mathrm{X}$

$\mathrm{X}$

$\mathrm{X}$

$\mathrm{X}$

$\mathrm{X}$

Observations

480

480

480

480

R-squared

0.124

0.115

0.113

0.131

Notes: Robust standard errors in parentheses. ${ }^{* * *} \mathrm{p}<0.01 ; * * \mathrm{p}<0.05,{ }^{*} \mathrm{p}<0.10$. Independent variables in Panel A: region dummies (not shown), industrial concentration, \% black, and prejudice index in 1991. Independent variables in Panel B: region dummies, 1991 levels of industrial concentration, \% black, and prejudice index, and changes in average wages by level of schooling (not shown). Industrial concentration, \% black, and prejudice index are standardized. Unit of observation is a micro-region. Census data from 1991 and 2000. Regressions weighted by the precision of first-stage estimates of the dependent variable (inverse of the standard errors). First stage is a regression for 20-60 year-old male employees. First stage independent variables: age, age squared, dummies for years of schooling, urban area, and micro-region, and interactions between a dummy for white and micro-region dummies. 


\section{Appendix A: Additional Tables}

Table A.1: Employment Share by Sector - Brazil, 1991 Census

\begin{tabular}{|c|c|c|}
\hline & \multicolumn{2}{|c|}{1991} \\
\hline & Including services & Excluding services \\
\hline Agriculture & 21.63 & 55.45 \\
\hline Mineral mining & 0.80 & 2.05 \\
\hline Petroleum, gas extraction & 0.11 & 0.28 \\
\hline Nonmetallic metallic & 0.94 & 2.41 \\
\hline Metals & 2.75 & 7.05 \\
\hline Machinery, equipment & 0.50 & 1.28 \\
\hline Electric, electronic equipment & 0.54 & 1.38 \\
\hline Transport & 0.59 & 1.51 \\
\hline Wood, furniture & 1.67 & 4.28 \\
\hline Paper, publishing, printing & 0.87 & 2.23 \\
\hline Rubber & 0.16 & 0.41 \\
\hline Chemicals & 0.73 & 1.87 \\
\hline Petroleum refining & 0.17 & 0.44 \\
\hline Pharma, perfumes & 0.22 & 0.56 \\
\hline Plastic & 0.34 & 0.87 \\
\hline Textiles & 1.06 & 2.72 \\
\hline Apparel & 2.52 & 6.46 \\
\hline Footwear & 0.74 & 1.90 \\
\hline Food processing & 2.33 & 5.97 \\
\hline Other manufacturing & 0.34 & 0.87 \\
\hline Services & 61.00 & - \\
\hline Total & 100 & 100 \\
\hline
\end{tabular}


Table A.2: Matching of Sectors between Kume et al. (2003) and the 1991 Census

\begin{tabular}{|c|c|c|c|c|}
\hline \multicolumn{2}{|r|}{ Kume et al (200) } & \multirow{2}{*}{$\begin{array}{r}1991 \text { Census } \\
11-37,41,42,581\end{array}$} & \multicolumn{2}{|l|}{ Aggregated } \\
\hline & Agriculture & & Agriculture & 1 \\
\hline 2 & Mineral mining & $50,53-59$ & Mineral mining & 2 \\
\hline 3 & Petroleum, gas extraction & 51,52 & Petroleum, gas extraction & 3 \\
\hline 4 & Nonmetallic mineral & 100 & Nonmetalic mineral & 4 \\
\hline 5 & Metals & 110 & Metals & 5 \\
\hline 6 & Nonmetallic manufacturing & 110 & Metals & 5 \\
\hline 7 & Other nonmetalic manufacturing & 110 & Metals & 5 \\
\hline & Machinery, equipment & 120 & Machinery, equipment & 6 \\
\hline & Electric materials & 130 & Electric, electonic equipment & 7 \\
\hline & Electonic equipment & 130 & Electric, electonic equipment & 7 \\
\hline 12 & Automobile, transportation & 140 & Transport & 8 \\
\hline & Vehicle parts, other vehicles & 140 & Transport & 8 \\
\hline 14 & Wood, furniture & $150,151,160$ & Wood, furniture & 9 \\
\hline 15 & Paper, publishing, printing & 170,290 & Paper, publishing, printing & 10 \\
\hline 16 & Rubber & 180 & Rubber & 11 \\
\hline & Chemicals & 200 & Chemicals & 12 \\
\hline & Petroleum refining & $201,202,352,477$ & Petroleum refining & 13 \\
\hline 19 & Other chemicals & 200 & Chemicals & 12 \\
\hline & Pharma, perfume & 210. 220 & Pharma, perfume & 14 \\
\hline 21 & Plastic & 230 & Plastic & 15 \\
\hline & Textile & 240. 241 & Textile & 16 \\
\hline 23 & Apparel & 250,352 & Apparel & 17 \\
\hline & Footwear & 190,251 & Footwear & 18 \\
\hline 25 & Coffee & $260,261,270,280$ & Food processing & 19 \\
\hline & Vegetables & $260,261,270,280$ & Food processing & 19 \\
\hline & Animal Slaughter & $260,261,270,280$ & Food processing & 19 \\
\hline & Dairy & $260,261,270,280$ & Food processing & 19 \\
\hline & Sugar & $260,261,270,280$ & Food processing & 19 \\
\hline 30 & Vegetable oils & $260,261,270,280$ & Food processing & 19 \\
\hline & Other food processing & $260,261,270,280$ & Food processing & 19 \\
\hline & Other manufaturing & 300 & Other manufaturing & 20 \\
\hline
\end{tabular}


Table A.3: Impact of Tariff Change on Racial Wage Gap by Level of Schooling, Brazilian Micro-regions, 1991-2000 - Dependent Variable: Change in Conditional Racial Wage Gap Conditional Racial Wage Gap in the $1^{\text {st }}$ Stage Estimated by Level of Schooling

Schooling levels:

\begin{tabular}{|c|c|c|c|c|}
\hline & \multicolumn{4}{|c|}{ Schooling levels: } \\
\hline & $\begin{array}{c}\text { Primary } \\
\text { School } \\
(1)\end{array}$ & $\begin{array}{c}\text { Elementary } \\
\text { School } \\
(2)\end{array}$ & $\begin{array}{c}\text { High } \\
\text { School } \\
(3)\end{array}$ & $\begin{array}{c}\text { College/ } \\
\text { University } \\
(4)\end{array}$ \\
\hline$\Delta($ tariff $)$ & $\begin{array}{l}0.116^{*} \\
(0.064)\end{array}$ & $\begin{array}{c}0.386^{* * *} \\
(0.102)\end{array}$ & $\begin{array}{c}0.118 \\
(0.103)\end{array}$ & $\begin{array}{l}-0.358 \\
(0.331)\end{array}$ \\
\hline Observations & 480 & 479 & 479 & 464 \\
\hline R-Squared & 0.060 & 0.353 & 0.414 & 0.366 \\
\hline 1991wage gap & 0.105 & 0.113 & 0.112 & 0.113 \\
\hline$\Delta(\mathrm{w}$ gap $)$ & 0.000 & -0.010 & 0.003 & 0.023 \\
\hline $\begin{array}{l}\text { Notes: Robust stand } \\
\text { variables: region dun } \\
\text { of observation is a } \\
\text { precision of first-stag } \\
\text { stage is a regression } \\
\text { age squared, dumm } \\
\text { between a dummy fo }\end{array}$ & $\begin{array}{l}\text { ors in pare } \\
\text { nd changes } \\
\text { gion. Censt } \\
\text { lates of the } \\
60 \text { year-old } \\
\text { years of sc }\end{array}$ & $\begin{array}{l}\text { s. }{ }^{* * *} \text { p }<0.01 ; \\
\text { erage wages by } 1 \\
\text { a from } 1991 \text { and } \\
\text { dent variable (ir } \\
\text { employees. Firs } \\
\text { g, urban area, } \\
\text { dummies. }\end{array}$ & $\begin{array}{l}0.05,{ }^{*} \mathrm{p} \\
\text { of schooling } \\
\text {. Regressio } \\
\text { e of the sta } \\
\text { ge indepen } \\
\text { micro-regio }\end{array}$ & $\begin{array}{l}\text { 10. Independent } \\
\text { lot shown). Unit } \\
\text { weighted by the } \\
\text { ard errors). First } \\
\text { t variables: age, } \\
\text { and interactions }\end{array}$ \\
\hline
\end{tabular}


Table A.4: Impact of Tariff Change on Racial Wage Gap Controlling for Informality in the First Stage, Brazilian Micro-regions, 1991-2000 - Dependent Variable: Change in Conditional Racial Wage Gap

\begin{tabular}{|c|c|c|c|c|}
\hline & $(1)$ & $(2)$ & $(3)$ & (4) \\
\hline$\Delta($ tariff $)$ & $\begin{array}{c}0.138^{* *} \\
(0.069)\end{array}$ & $\begin{array}{c}0.160^{* *} \\
(0.072)\end{array}$ & $\begin{array}{c}0.223^{* * *} \\
(0.065)\end{array}$ & $\begin{array}{c}0.242^{* * *} \\
(0.065)\end{array}$ \\
\hline$\Delta($ primary wage $)$ & & & $\begin{array}{c}-0.162^{* * *} \\
(0.030)\end{array}$ & $\begin{array}{c}-0.149^{* * * *} \\
(0.034)\end{array}$ \\
\hline$\Delta$ (elementary wage $)$ & & & $\begin{array}{c}0.038 \\
(0.034)\end{array}$ & $\begin{array}{c}0.029 \\
(0.035)\end{array}$ \\
\hline$\Delta$ (high school wage) & & & $\begin{array}{c}0.039 \\
(0.027)\end{array}$ & $\begin{array}{c}0.062^{* *} \\
(0.028)\end{array}$ \\
\hline$\Delta$ (college wage $)$ & & & $\begin{array}{c}0.008 \\
(0.012)\end{array}$ & $\begin{array}{c}0.011 \\
(0.012)\end{array}$ \\
\hline Region Dummies & & $\mathrm{X}$ & $\mathrm{X}$ & \\
\hline State Dummies & & & & $\mathrm{X}$ \\
\hline Observations & 480 & 480 & 480 & 480 \\
\hline R-Squared & 0.009 & 0.046 & 0.111 & 0.169 \\
\hline
\end{tabular}

Notes: Robust standard errors in parentheses. ${ }^{* * *} \mathrm{p}<0.01 ;{ }^{* *} \mathrm{p}<0.05,{ }^{*} \mathrm{p}<0.10$. First stage is a regression for 20-60 year-old male employees. First stage independent variables include all variables included in the first stage of Table 2, plus an indicator for informal employment (without a signed labor card): age, age squared, dummies for years of schooling, urban area, and micro-region, interactions between a dummy for white and micro-region dummies, and informality dummy. Second stage independent variables: region and state dummies (not shown), and changes in micro-region average wages by level of schooling (primary, elementary, high school, and college). Unit of observation is a micro-region. Census data from 1991 and 2000. Regressions weighted by the precision of first-stage estimates of the dependent variable (inverse of the standard errors). 
Table A.5: Individual Level Estimates of the Impact of Tariff Change on Racial Wage Gap, Brazilian Micro-regions, 1991-2000 - Dependent Variable: Natural Logarithm of Hourly Wage

\begin{tabular}{cccccccc}
\hline \multicolumn{1}{c}{$(1)$} & $(2)$ & $(3)$ & $(4)$ & $(5)$ & $(6)$ & $(7)$ \\
\hline \multirow{2}{*}{ white $\times$ tariff } & $0.355^{* * *}$ & $0.242^{* * *}$ & $0.255^{* * *}$ & $0.241^{* * *}$ & $0.249^{* * *}$ & $0.243^{* * *}$ & $0.268^{* * *}$ \\
& $(0.061)$ & $(0.039)$ & $(0.038)$ & $(0.039)$ & $(0.040)$ & $(0.038)$ & $(0.039)$
\end{tabular}

Controls:

$\begin{array}{lllllllll}\text { Individual Characts. } & \text { X } & \text { X } & \text { X } & \text { X } & \text { X } & \text { X } & \text { X }\end{array}$

Agg. Micro-region Vars.:

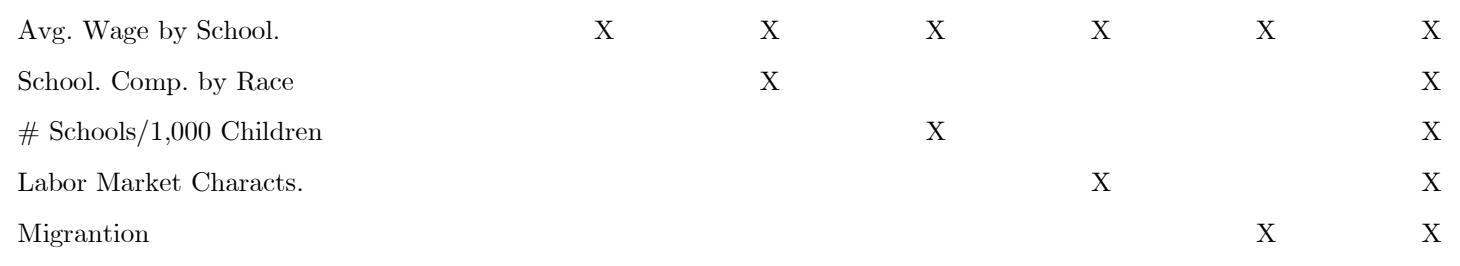

$\begin{array}{lccccccc}\text { Year dummies } & \mathrm{X} & \mathrm{X} & \mathrm{X} & \mathrm{X} & \mathrm{X} & \mathrm{X} & \mathrm{X} \\ \text { Micro-region dummies } & \mathrm{X} & \mathrm{X} & \mathrm{X} & \mathrm{X} & \mathrm{X} & \mathrm{X} & \mathrm{X} \\ \text { Observations (millions) } & 4.01 & 4.01 & 4.01 & 4.01 & 4.01 & 4.01 & 4.01 \\ \text { R-squared } & 0.512 & 0.516 & 0.516 & 0.516 & 0.516 & 0.516 & 0.516\end{array}$

Notes: Robust standard errors in parentheses (clustered at micro-region level). ${ }^{* * *} \mathrm{p}<0.01 ;{ }^{* *} \mathrm{p}<0.05,{ }^{*} \mathrm{p}<0.10$. Individual controls: age, age squared, dummies for years of schooling, dummy for urban area, and interactions with the year dummy. Aggregate (micro-region) controls: region dummies, average wages by level of schooling, composition of the labor force by level of schooling and race, number of public schools per 1,000 children, share of informal employees, $\%$ of unemployed, and \% of migrants. Unit of observation is an individual. Census data from 1991 and 2000. 
Table A.6: Long-term Impact of Tariff Change on Racial Wage Gap, Brazilian Micro-regions, 1991-2010 - Dependent Variable: Change in Conditional Racial Wage Gap between 1991 and 2010

\begin{tabular}{|c|c|c|}
\hline & (1) & $(2)$ \\
\hline$\Delta($ tariff $)$ & $\begin{array}{c}0.285^{* * *} * \\
(0.081)\end{array}$ & $\begin{array}{c}0.275^{* * *} \\
(0.084)\end{array}$ \\
\hline$\Delta($ primary wage $)$ & $\begin{array}{c}-0.144^{* * *} \\
(0.029)\end{array}$ & $\begin{array}{c}-0.126^{* * *} \\
(0.037)\end{array}$ \\
\hline$\Delta$ (elementary wage $)$ & $\begin{array}{c}0.023 \\
(0.037)\end{array}$ & $\begin{array}{c}0.004 \\
(0.040)\end{array}$ \\
\hline$\Delta$ (high school wage) & $\begin{array}{c}0.043 \\
(0.035)\end{array}$ & $\begin{array}{c}0.059 \\
(0.037)\end{array}$ \\
\hline$\Delta($ college wage $)$ & $\begin{array}{l}0.033^{*} \\
(0.020)\end{array}$ & $\begin{array}{c}0.027 \\
(0.022)\end{array}$ \\
\hline Region Dummies & $\mathrm{X}$ & \\
\hline State Dummies & & $\mathrm{X}$ \\
\hline Observations & 488 & 488 \\
\hline R-Squared & 0.118 & 0.171 \\
\hline \multicolumn{3}{|c|}{$\begin{array}{l}\text { Notes: Robust standard errors in parentheses. }{ }^{* * *}<<0.01 ;{ }^{* *} \mathrm{p}<0.05,{ }^{*} \mathrm{p}< \\
0.10 \text {. First stage is a regression for } 20-60 \text { year-old male employees. First stage } \\
\text { independent variables include all variables included in the first stage of Table } 2 \text {, } \\
\text { plus an indicator for informal employment (without a signed labor card): age, } \\
\text { age squared, dummies for years of schooling, urban area, and micro-region, } \\
\text { interactions between a dummy for white and micro-region dummies, and } \\
\text { informality dummy. Second stage independent variables: region and state } \\
\text { dummies (not shown), and changes in micro-region average wages by level of } \\
\text { schooling (primary, elementary, high school, and college). Unit of observation is } \\
\text { a micro-region. Census data from } 1991 \text { and 2010. Regressions weighted by the } \\
\text { precision of first-stage estimates of the dependent variable (inverse of the } \\
\text { standard errors). }\end{array}$} \\
\hline
\end{tabular}




\section{Appendix B: Constructing Compatible Micro-regions across Censuses}

The division of the Brazilian territory into municipalities and micro-regions changes substantially between 1991 and 2000. In particular, due to political secession, 1015 new municipalities are created during this period. Some of them incorporate fractions of territory that previously belonged to different municipalities and, sometimes, to different micro-regions.

To deal with this problem, we use Minimum Comparable Areas (MCAs), which define geographic units that are comparable across censuses (Reis et al., 2011). We start with the 4492 MCAs that are comparable across 1991 and 2000 and use the geographic definition of micro-regions from 2000. Whenever a given AMC crosses a micro-region boundary in 2000, we aggregate the micro-regions to which this AMC belongs into a new consolidated micro-region. Proceeding like this, we are able to generate a consistent set of micro-regions that correspond exactly to the same geographic areas in 1991 and 2000. By aggregating some of the micro-regions in this process, we reshape the 558 units that existed in 2000 into 494 units.

For our benchmark sample of men, aged between 20 and 60, with positive wages, and information on schooling, occupation, and urban residence, we further aggregate micro-regions that have too few observations for the conditional racial wage gap to be estimated precisely. So microregions with fewer than 500 observations in at least one of the census years are merged with the neighboring micro-region with lowest population. With this additional change, our set of microregions is reduced further by 6 units, leaving us with a final set of 488 micro-regions.

For the 285 compatible micro-regions from the 1980 and 1991 censuses used in the robustness exercises, we follow steps analogous to those adopted in the construction of the 19912000 areas, but using the micro-regions from 1991 as initial reference points (also following Reis et al., 2011). This procedure also keeps track of the changes in municipality borders between 1980 and 1991. 